\title{
In Military We Trust: The Effect of Managers' Military Background on Mutual Fund Flows*
}

\author{
Alexander Cochardt ${ }^{\dagger}$ \\ Stephan Heller ${ }^{\ddagger}$ \\ Vitaly Orlov $^{\S}$
}

\begin{abstract}
This paper shows that trust-building characteristics of fund managers affect purchase decisions of mutual fund investors. We exploit variation in fund managers' prior affiliations with the U.S. military, a well-trusted institution, and relate it to fund flows. Funds with ex-military managers receive significantly higher flows and have a $6.5 \%$ faster annual growth rate relative to other funds. Investor inclination toward these managers strengthens with their military involvement and its salience and with nationwide confidence in the military. Military managers' superiority in competition for investor funds is not due to variation in fund or managerial attributes and is robust to alternative explanations.
\end{abstract}

JEL classification: G11, G23.

Keywords: Trust; Mutual Funds; Investment Decision; Fund Managers; Military.

${ }^{*}$ The authors are grateful for the comments and suggestions of Stefano Giglio (discussant), Peter Limbach (discussant), Viktoriya Lantushenko (discussant), Vikas Agarwal, Pierre Collin-Dufresne, Kent Daniel, Owen Lamont, Mark Grinblatt, Lubos Pastor, Tobias Moskowitz, Clemens Sialm, Thomas Philippon, Sydney Ludvigson, Alexander Wagner, Alexandra Niessen-Ruenzi, Peter Bossaerts, Martin Brown, Markku Kaustia, Vadim Elenev, Renée Adams, Angelo Ranaldo, Paul Söderlind, Florian Weigert, and participants of the NBER Summer Institute 2019 Asset Pricing Workshop, SFI research days meeting, Finance Workshop in Davos, Cologne Colloquium on Financial Markets, SFA 2019 meeting and Brown Bag Seminar at University of St. Gallen.

${ }^{\dagger}$ University of St. Gallen, Swiss Institute of Banking and Finance, Unterer Graben 21, CH-9000 St. Gallen, Switzerland; Tel.: +41 71224 7005; E-mail address: alexander.cochardt@unisg.ch.

${ }^{\ddagger}$ University of St. Gallen, Swiss Institute of Banking and Finance, Unterer Graben 21, CH-9000 St. Gallen, Switzerland; Tel.: +41 71224 7004; E-mail address: stephan.heller@unisg.ch.

${ }^{\S}$ Corresponding author. University of St. Gallen, Swiss Institute of Banking and Finance, Unterer Graben 21, CH-9000 St. Gallen, Switzerland; Tel.: +41 71224 7003; E-mail address: vitaly.orlov@unisg.ch. 


\section{Introduction}

What determines the decision to invest in one mutual fund over another? On average, mutual funds are known to persistently underperform passive investment strategies net of fees (Jensen (1968); Carhart (1997)). Nonetheless, investors continue to pay billions of dollars in fees to managers and advisers absent proof that they provide sufficient performance to compensate for their fees (Bergstresser, Chalmers, and Tufano (2009); Fama and French (2010); Hoechle, Ruenzi, Schaub, and Schmid (2018)). That is, either the market for asset management is inefficient (investors pay fees without being compensated) or fund and manager-specific factors beyond returns alone guide the decision to invest in a mutual fund (Hortaçsu and Syverson (2004)). In this paper, we provide support for the view that distinct trust-building attributes of fund managers affect the purchase decisions of mutual fund investors.

Trust plays a pivotal role in the various decisions we make, from facilitation of personal relationships to participation in economic activities (Knack and Keefer (1997)). Investment decisions are no exception. As suggested by Guiso, Sapienza, and Zingales (2004), trust reflects a general reliance on the integrity and fairness of the financial system and may serve as an explanation to the limited stock market participation puzzle. With regard to asset management, Mullainathan, Schwartzstein, and Shleifer (2008) indicate that the majority of advertisement campaigns by investment advisers and mutual funds draw on trust and less on past performance. Kostovetsky (2015) shows that investors attach value to their relationship with the asset management company, which affects their capital allocation decisions when ownership changes. In the model of Gennaioli, Shleifer, and Vishny (2015), managerial qualities, personal connections, familiarity and persuasive advertising underlie trust in a manager, which helps reduce the investor's perception of the riskiness of investments and correspondingly justifies manager fees and influences investment decisions. Following this line of reasoning, we investigate whether potentially trust-related biographical characteristics

of mutual fund managers, specifically their prior engagement in the military, affect the investment choices of mutual fund investors.

A manager's prior military affiliation may promote investor trust for several reasons. We argue that such a background may serve as a signal that alleviates the investor's uncertainty regarding the manager's motives and prospective actions. First, military service demands a high degree of personal commitment and dedication that may translate to more compliant and ethical behavior in later civilian employment. Koch-Bayram and Wernicke (2018) find that ex-military CEOs are less inclined to engage in financial misconduct. In this regard, trust functions as an implicit contract, which serves as a substitute for costly monitoring, and investors likely prefer managers who require less monitoring. In addition, evidence from 
peer-to-peer lending suggests that lenders discriminate in favor of individuals that display signs of military involvement (Pope and Sydnor (2011)). Further, serving in the military may indicate a high level of patriotism, which has been found to provide important guidance for social behavior (Huddy and Khatib (2007)). Military service may also signify social identity. In particular, individuals tend to follow the actions of others seen as members of their own social group (Cialdini and Goldstein (2004)) and likely increase cooperation with them (Blader and Tyler (2009)). Thus, a shared social identity between investor and manager may induce trust. Finally, ex-military personnel may be perceived as being better able to fulfill the investor's expectations. The possibility of such perceptions is supported by research showing that the perceived qualities of ex-military individuals cast candidates in a positive light during electoral campaigns (Teigen (2013)), serve as a productivity screening device in a civilian labor market (De Tray (1982)), and enhance success in corporate executive positions (Duffy (2006)).

In this paper, we posit that mutual fund managers with prior military background have an advantage when competing for investor funds because they are perceived as having certain military-associated characteristics that foster trust. Consequently, investors are more likely to allocate capital to funds managed by military-experienced individuals, even in the absence of evidence suggesting that they have superior investment skills relative to their nonmilitary peers. In addition, we posit that such trust-mediated allocation of assets is likely to be more pronounced during episodes of extreme performance realization and heightened confidence in the military and when background information is presented saliently.

To investigate our hypothesis, we use a novel data set of U.S. equity mutual funds that contains biographical information of fund managers. The U.S. mutual fund setting entails unique opportunities for studying the effects of fund manager's military background on investor capital allocation decisions for two reasons. First, it allows disentangling effects related to a military background from differences in other fund or managerial attributes, including performance. Second, the U.S. military is the most trusted of all institutions in American society and is historically perceived to be an effective and well-run establishment. ${ }^{1}$ Likewise, U.S. military personnel are associated with the highest levels of honesty and ethical standards.

Our main empirical findings indicate that public information about a manager's prior military experience affects fund flows. Mutual funds managed by individuals with a military background have on average 10.6 percentage points higher annualized net flows relative to

\footnotetext{
${ }^{1}$ Historical survey data by Gallup Poll suggest that U.S. citizens - independent of their party affiliation - gave the highest confidence rating to the military, out of all institutions in society, including church, education, congress, presidency, newspapers (media), the police, the criminal justice and medical systems and so forth, in every year over the 1975-2017 period.
} 
comparable funds with managers who have a non-military background. Further, all else being equal, a mutual fund managed by an individual with a military background has an annualized growth rate that is up to $6.5 \%$ higher relative to other funds. The observed economically sizable effect of managers' military background on fund flows is not subsumed by variation in commonly used flow-related fund or manager-specific attributes. Further, it is robust to several alternative explanations and remains unchanged even when we restrict the analysis to funds that are almost identical in terms of main observable characteristics.

The results from several additional tests indicate that the content and salience of information disclosures of a military background influence mutual fund investor decisions. We find that fund managers whose military service is disclosed as being prolonged and including heroic achievements and meritorious service in a combat zone attract additional annual flows of $6.5 \%$ compared with managers who only disclose that they served in the military. The fund flow effect is more pronounced when investors are exposed to salient, eye-catching information and when they obtain this information with little effort on their part. Moreover, the effect of managers' military background only occurs in the sample of single-managed funds; it is suppressed in team-managed funds. In addition, confirming the presumption that military background may serve as a substitute for costly monitoring and reduce investors' perception of investment riskiness, we find that ex-military managers are less likely to engage in window dressing activities and overall exhibit more ethical behavior relative to their nonmilitary peers.

We perform several tests to investigate the relation between the managers' military experience and fund flows more closely. Our findings shed light on the role that trust may play in investor decisions. An association exists between investors' buying and selling behavior toward military-managed mutual funds and the nationwide confidence in the U.S. military and perception of security. We find that periods with a high level of trust in public institutions, and the military in particular, are associated with distinct partisan attitudes of investors toward military-managed funds. In contrast, during periods of relatively low confidence in the military and low perceived security, investors tend to allocate less capital to funds managed by ex-military individuals. Moreover, we observe that ex-military managers' fund flows plunge following the exogenous events of military-related scandals that may have adversely affected trust in the military.

To further support the trust-related asset allocation conjecture, we conduct a differencein-differences analysis around the dates of managerial turnover. In the absence of any other fundamental events and all else being equal, managers with a military background receive net fund inflows that are 5.7 percentage points higher during the first month of active management relative to other managers. The difference in fund flows following the induction 
of military-experienced managers is persistent, while the two groups exhibit parallel movements in fund flow outcomes in the absence of a manager change. We also show that flow differences between military- and nonmilitary-managed funds are particularly large for extreme performance realizations. Military managers have higher fund flows relative to their nonmilitary counterparts following both extremely good and extremely poor fund performance. Collectively, the results of these tests support the conjecture that trust induced by a manager's military background influences mutual fund investors' decisions.

In addition, we determine that a substantial fraction of investors are likely to consider fund manager background information when making their investment decisions. First, we perform an online survey of mutual fund investors. The survey results indicate that the majority of mutual fund investors know their fund managers and are aware of the manager's profile when they are investing. Second, we conduct an online fund investment experiment to gather additional evidence on the relation between a manager's military background and fund flows. In the experiment, we ask participants (U.S. mutual fund investors) to allocate money between two funds. We keep the fund and basic manager information constant, but we randomly assign a military background to managers. Results indicate that participants invest significantly more money into a fund when it has an ex-military manager. In contrast, when we specify no prior military affiliation for managers of both funds, we find no significant difference in asset allocation.

Our finding of ex-military managers' relative superiority in attracting fund flows raises an intriguing equilibrium question: Why would not all mutual funds employ militaryexperienced individuals? A potential answer is that the supply of qualified individuals with military experience may be too limited to meet the increasing demand for mutual fund managers over the sample period of our study. This limitation may consequently prevent fund management companies from appointing more ex-military individuals to their funds, even though such appointments would be advantageous. In the same vein, Benmelech and Frydman (2015) suggest that firms are constrained in hiring corporate executives with a military background because the supply of such individuals is insufficient. In addition, we consider several alternative answers to our question; for example, fund management companies may simply be unaware of the flow effect we uncover, or ex-military managers may perform worse. However, we do not find these explanations to be consistent with our data. Finally, we acknowledge other potential costs of hiring ex-military managers (e.g., the possibility of higher compensation), which we are not able to address within our setting and leave for future research.

Our empirical findings are consistent with the broad implications of portfolio management delegation models, which emphasize the role of trust (Gennaioli et al. (2015)). In particular, 
our findings support the view that trust in the manager that is induced by salient background information may reduce investors' perception of investment riskiness. Investors who seek to reduce anxiety around risky investment choices hire a money manager and base the hiring on manager characteristics. Thus, military-experienced managers are likely to be perceived as money guardians having military-associated qualities. While our study does not directly test the Gennaioli et al. (2015) theory, our key results can be interpreted naturally under the description of trust-mediated fund allocation that this theory offers. Our findings that trust induces fund flows also support the key premises of theoretical models of coarse thinking (Mullainathan et al. (2008)) and strategic persuasion (Glazer and Rubinstein (2004)).

The empirical findings in our study further contribute to the vast literature on the determinants of mutual fund flows. Previous studies relate fund flows to various fund and managerial characteristics, including past fund performance (Berk and Green (2004), among others), advertisement (Jain and Wu (2000)), fund name changes (Cooper, Gulen, and Rau (2005)), fund ratings (Del Guercio and Tkac (2008)), manager gender (Niessen-Ruenzi and Ruenzi (2018)), and manager name (Kumar, Niessen-Ruenzi, and Spalt (2015)), among others. On a general level, our study relates to that of Cici, Gehde-Trapp, Göricke, and Kempf (2018), who show that both fund managers and fund families can benefit from a manager's experience outside the fund management industry.

More broadly, our study adds to the literature that emphasizes how the unique attributes of military-experienced managers affect economic outcomes (Malmendier, Tate, and Yan (2011); Benmelech and Frydman (2015)). Evidence from our study also complements earlier literature on how an individual's military experience influences later life socioeconomic achievements (Sampson and Laub (1996); MacLean and Elder Jr (2007)) and aids the development of qualities that can be beneficial in the labor market (Jackson, Thoemmes, Jonkmann, Lüdtke, and Trautwein (2012)). To the best of our knowledge, our study is the first to relate prior military experience to asset management and to analyze customer-based perception of ex-military individuals.

The remainder of the paper proceeds as follows. Section 2 describes the data set and the data collection process and provides basic statistics. Section 3 focuses on the relationship at the center of the study and examines the effect of a manager's military background on fund flows. Section 4 presents evidence that the observed relationship can be attributed to military-associated partisanship. Section 5 presents the supplementary analysis, followed by Section 6, which concludes the paper. 


\section{Data and Sample Design}

We rely on multiple data sources to identify our sample and obtain information for the empirical analysis. In this section, we describe these data sources, outline the process of identifying managers with a military background, and provide the sample descriptive statistics. Appendix A provides supplementary details on the construction of all main variables used in the empirical part of the study.

\subsection{Data on Mutual Funds}

Data on mutual funds come from CRSP Survivor-Bias-Free U.S. Mutual Fund Database (CRSP MF) and Morningstar Direct Mutual Fund Database (MS Direct). First, we obtain data on fund share class characteristics for the set of actively managed domestic equity-only U.S. mutual funds from the CRSP MF. The data are then aggregated at the fund level by weighting the respective fund share classes with the corresponding total net assets. The main variable of interest in the empirical analysis is net fund flows. We do not observe flows directly, so we infer flows from fund returns and total net assets. Following standard practice in the literature (e.g., Sapp and Tiwari (2004); Frazzini and Lamont (2008)), we compute flows $F_{t}^{i}$ for fund $i$ in month $t$ as

$$
F_{t}^{i}=\frac{T N A_{t}^{i}-T N A_{t-1}^{i}}{T N A_{t-1}^{i}}-r_{t}^{i}
$$

where $T N A_{t}^{i}$ is fund $i$ 's total net assets in month $t$ and $r_{t}^{i}$ stands for fund $i$ 's net return in month $t$. To ensure that the results are not unduly influenced by outliers, we follow Kumar et al. (2015) and drop fund flow observations below the 1st percentile and those above the 99th percentile. ${ }^{2}$

Second, we establish a match between MS Direct and CRSP MF fund classes by carefully following the data appendix provided by Pástor, Stambaugh, and Taylor (2015), who identify matches relying on CUSIPs as well as the funds' tickers. Further, we restrict the sample to include only the funds that were managed by a single manager for at least one month over their entire lifespan. ${ }^{3}$ Following the rationale of Agarwal, Ma, and Mullally (2015), we exclude cases in which single managers run more than four funds at the same time because these managers are likely to be team managers. We also remove funds reportedly managed

\footnotetext{
${ }^{2}$ Additionally, we check that the main results persist when we use raw fund flows, winsorize the observations, drop observations below the 5th percentile and above the 95th percentile, or exclude funds with total net assets lower than $\$ 1$ million.

${ }^{3}$ Although we also consider a sample of team-managed funds in Table 6 , our focus in this study is on single-managed mutual funds.
} 
by anonymous managers.

To obtain the data on fund holdings, we match CRSP MF with Thomson Reuters Mutual Fund Holdings Database (MF Holdings) using the MFLINKS tables. Only holdings of common stocks (share codes 10 and 11) are considered, and information on stocks is obtained from CRSP and Compustat databases.

\subsection{Identifying Managers with a Military Background}

We obtain the fund manager names as well as the start and end dates of their management period at the respective fund via MS Direct. The choice of this database is in line with Patel and Sarkissian (2017), who show that the fund manager information provided by MS Direct is more accurate than the data provided by CRSP MF. We extract the fund managers' short profiles and, if available, information on academic degrees, certifications, and affiliations from MS Direct. We restrict the sample to all fund-month observations for which a single manager was managing the fund for at least one month. In total, after the Morningstar-CRSP match, we identify 2,903 funds over the sample years from 1991 to 2017.

To establish a complete profile for each manager, we perform a comprehensive crossdatabase search and obtain additional information from Morningstar, Bloomberg, Marquis Who's Who, Financial Industry Regulatory Authority (FINRA), LinkedIn, SEC filings, Intelius database, GI Search engine, Ancestry.com, Legacy.com, fund company websites, and articles in U.S. newspapers from LexisNexis and Newspapers.com. To guard against the possibility of wrong matches, we drop observations from the sample whenever we get multiple matching profiles or conflicting information from various sources. We restrict our sample to fund managers for whom we observe Morningstar and/or Bloomberg profiles and identify the date of birth. As a result, we are able to collect information on the personal characteristics and complete biographical information, including the prior military background of the fund managers. If a military affiliation exists for a manager, we can usually extract an extensive military profile, including information about training, dates of service, involvement in military conflicts, military rank, and military awards. ${ }^{4}$ Figure B.1, Figure B.2, and Figure B.3 in Appendix B provide military profile examples from Morningstar, Bloomberg, and fund firm advertising materials.

Importantly, we define a fund manager as having military experience prior to joining the fund management industry only if this information was available to investors during the manager's corresponding active management period. For example, the manager's Morningstar, Bloomberg, LinkedIn or fund company website profile at the time of active management

\footnotetext{
${ }^{4}$ However, in some cases we have to rely only on vague background description, e.g. "... was a decorated officer in the U.S. Marine Corps..."
} 
may clearly state the prior military experience. If the manager was active in the past, we make sure (ensure) that such information was freely circulating and available to investors at some point during the manager's active period. Specifically, for each fund manager in our sample we review whether information on military affiliation was disclosed in SEC filings, prospectuses, U.S. newspapers, or any of the manager and fund family-related internet resources during the manager's active period. We further enrich this data by combining it with legacy web content from fund firms' historical websites that we access (accessible) through the Internet Archive's Wayback Machine available at archive.org. ${ }^{5}$

In total, our final sample consists of 1,858 (73.92\% of total) individuals single-managing 2,448 funds ( $84.33 \%$ of funds that were single-managed for at least one month). Within this set, 229 of the funds (9.35\% of the sample) are single-managed by 123 (6.62\% of the sample) managers with a military background (served in the military). ${ }^{6}$ Additionally, we identify 159 funds that were managed by teams that included at least one manager with military experience.

\subsection{Sample Characteristics}

Table 1 separately reports statistics for funds managed by individuals with and without prior military experience. Comparing the sample means for the two groups of funds, we find a significant difference in the net fund flow measure but not in other characteristics. Mutual funds run by managers with a military background have annualized fund flows that are 10.6 percentage points higher relative to funds managed by nonmilitary individuals (t-statistic of 5.06). In contrast, we observe no economically or statistically significant variation across the groups in any other fund characteristic, including return, risk, size, age, expenses, and turnover. There are no differences in the distribution channels, the Morningstar ratings, or the share of expenses set aside for marketing purposes. Importantly, we observe virtually no heterogeneity in portfolio holdings between military and nonmilitary managers. For

\footnotetext{
${ }^{5}$ For every domain of a fund firm's website, we request the full history of all snapshots recorded by the Internet Archive. We download the entire content linked to the last available snapshot of a given month by querying the Wayback Machine's API. Fund firms from our sample start registering domains in 1993. First websites are launched in 1995 and usually commented or advertised in newspapers. The earliest snapshots of our fund firms' websites in the archive date back to 1996, the first year the Internet Archive started to crawl the web. We retrieve domains of fund firms that have closed down or changed their domain name through advertisements and articles in historical newspapers via newspapers.com. In addition, we are able to retrieve historical domain names through Usenet newsgroups and finance related magazines (e.g., Kiplinger's Personal Finance).

${ }^{6}$ This number compares favorably to the share of military-experienced managers documented in the corporate finance literature. Benmelech and Frydman (2015) show that the share of ex-military corporate executives is approximately $6 \%$ in recent years. Moreover, the overall share of individuals who served in the military is $6.3 \%$ of the total U.S. population according to the Department of Veterans Affairs Veteran Population Projection Model 2016.
} 
example, managers with military experience do not invest more in defense stocks relative to other managers.

Manager characteristics show no statistically significant variation across the two groups in most cases. In particular, we find no difference between military and nonmilitary managers' marital status, educational background, mutual fund industry experience, fund tenure, namespecific attributes, or media coverage. The only exception is that managers with prior military experience tend to be older. Later in this paper, we show that the main result on the relation between military background and fund flows remains unaltered after controlling for the managers' biological age.

\subsection{A First Look at the Military Trust - Fund Flow Relationship}

To preliminarily explore whether military-related attitudes affect the decisions of U.S. mutual fund investors, we plot the average annual fund flow difference between managers with and without military background against Gallup Poll's survey-based military confidence index.

As an illustrative example for this link, Figure 1 depicts the evolution of the two indicators over time. The dynamics of the fund flow difference coincide reasonably well with the evolution of the military confidence index. Managers with military experience enjoy higher relative fund inflows during periods of high confidence in the U.S. military institution, while episodes of relative fund outflows occur around periods of low confidence in the military. The correlation coefficient is 0.41. Further, the extreme values of Gallup Poll's measure of satisfaction in the nation's military strength and preparedness (for the periods when available) also correspond to the episodes of relatively large inflows/outflows into/from the funds managed by military-experienced individuals. This simple relationship suggests a potential role of military-related partisanship in the asset allocation process of mutual fund investors.

\section{Military Background of Mutual Fund Managers and Fund Flows}

This section presents empirical results on the relation between military experience of mutual fund managers and fund flows. 


\subsection{Baseline results}

Given that the U.S. military has the highest confidence (trust) rating among all institutions in American society throughout the sample years, we conjecture that social affection and military-associated partisanship may affect asset allocation decisions of mutual fund investors. Therefore, prior military experience of mutual fund managers, other traits being equal, could draw capital flows into funds managed by such individuals. To test this conjecture, we examine aggregate investor behavior at the fund level and investigate whether military-managed funds attract higher inflows than nonmilitary-managed funds. In particular, we estimate regressions with monthly net fund flows as the dependent variable.

In the regression analysis, we relate net fund flows to a Military dummy variable that equals one if the fund is single-managed in a given month by an individual with prior military experience and zero if a manager does not have a military background. Importantly, the Military indicator variable covers only fund managers whose background information is publicly available to the investors during the managers' active management period. The set of controls is composed of fund characteristics, including Fund return, Fund performance rank, Fund size, Fund age, Fund risk, Expense ratio, Turnover ratio, Family flows and Lagged fund flows, and manager-specific attributes, such as Fund tenure and mutual fund Industry tenure. Fund performance rank is computed as the performance relative to all other funds in the same market segment in a given month. Fund risk is the time series standard deviation of the fund return using the rolling past 12-month return observations. Segment is based on the Morningstar fund style indicator, and controls are lagged by one month. We double-cluster standard errors by year and fund to allow for correlation between repeated observations from the same fund, and we show that our results are unlikely to be induced by some unobservable factors or any heterogeneous trends by including period, segment, family, fund, and interaction fixed effects. Estimation results are presented in Table 2.

The results of the flow regressions are consistent with the conjecture that militaryexperienced mutual fund managers, all else being equal, attract higher fund flows. Flows into military-managed funds are significantly higher than those into nonmilitary-managed funds. The coefficients on the main variable of interest, the Military dummy, are positive and statistically significant in all specifications of the model. In column (1), we present the estimates after including time-varying control variables but no fixed effects. The impact of the Military dummy is positive and significant at the $1 \%$ level (coefficient $=0.005$, t-stat. $=$ 3.80). In columns (2) through (6), we add various fixed effects as well as alternative controls for fund performance and lagged fund flows.

Specifically, in columns (2) through (4), we present estimates of the specifications with segment, year, and segment-by-month-year fixed effects. The coefficient estimates on the 
Military dummy are positive and significant at the $1 \%$ level, ranging from 0.003 to 0.005 . Further, a possibility exists that fund families that are better at attracting client flows are also better at attracting managers with potentially beneficial characteristics such as military experience. In addition, families that are better at marketing may also provide more information about their managers. Thus, in column (5) we include family-by-monthyear fixed effects. In this setting we are able to compare flows to funds with and without an ex-military manager in the same family at the same time. Comparing within familymonth-year, we observe a similar magnitude of the military effect with the point estimate on the Military dummy being once again positive and statistically significant (coefficient $=0.003$, t-stat. $=2.16)$. In column $(6)$, we include fund fixed effects, which allows us to identify the military manager effect from managerial turnover within funds and to control for unobservable factors at the fund level that can potentially influence fund flows. The estimate on the Military indicator is positive (coefficient $=0.003$ ) and statistically significant (t-stat. $=1.93)$. This outcome suggests that neither time-invariant unobserved heterogeneity at the segment, family, or fund level, nor time-varying heterogeneous trends drive our results. ${ }^{7}$ Overall, this section indicates that fund managers' military experience is positively related to fund flows.

The effect is also economically significant: the coefficient estimates imply that a fund managed by an individual with a military background, depending on the model specification, grows by about 3.2 to 6.5 annualized percentage points more than a comparable fund run by a manager with no military experience. The magnitude compares favorably to the mean annual net fund flows of $22.4 \%$ in Table 1.

\subsection{Robustness of the Results}

In this section, we closely consider several alternative explanations for our baseline findings. Results are presented in Table 3.

First, we ensure that our results are robust to several conventional alterations of our main setup. Kronlund, Pool, Sialm, and Stefanescu (2019) show that saliently presented information about long-term mutual fund performance, particularly one-year returns, affects investor capital allocation decisions. Therefore, in tests (1) through (3) we augment the baseline flow regression (column 3 of Table 2) with controls for past performance, namely three-month, one-year, and five-year returns. Although past performance appears to be an important determinant of flows, results of these tests indicate that the observed military

\footnotetext{
${ }^{7}$ In addition, we check that the observed military effect remains unchanged when we double-cluster standard errors on fund family and month-year (coefficient $=0.003$, t-stat. $=2.79$ ) instead of fund level and month-year as in the baseline specification (3) of Table 2.
} 
effect is not attenuated. We find that the estimates are significant and remarkably similar in economic magnitude to the baseline results, even in a more limited sample of test (3).

Demographic attributes of mutual fund managers may influence fund flows. NiessenRuenzi and Ruenzi (2018) show that gender-related discrimination affects fund flows, such that female-managed funds receive significantly lower inflows than similar male-managed funds. Roussanov and Savor (2014) show that single men, including mutual fund managers, are substantially different in managerial behavior relative to married men, while research in psychology suggests that people tend to trust married individuals more than single individuals (Rahn and Transue (1998)). Inclusion of demographic controls in test (5) shows that inferences remain unchanged, suggesting that our results are not simply a by-product of demographic attributes. ${ }^{8}$

Alternatively, our main variable of interest may indirectly proxy for manager's educational background because military service can pave the way to a better and less expensive education through various military tuition assistance programs. Indeed, in Table 1, we show that military managers on average are slightly better educated, being more likely to have a graduate degree. However, the results reported in test (6) indicate that our inferences do not change when we account for the educational effects on fund flows.

Network may be another factor that affects fund flows. Agarwal, Lu, and Ray (2018) show that money managers use opportunities to network and attract fund flows even when attending charitable events. Cohen, Frazzini, and Malloy (2008) report that mutual fund managers benefit from shared educational networks with corporate board members, and the benefit is particularly pronounced for graduates of highly recognized institutions. In test (7), we check whether the higher networking potential of Ivy League graduates affects our results. We also recognize that the wealth and income of mutual fund managers' parents affect future fund performance (Chuprinin and Sosyura (2018)). Correspondingly, we propose that the parental professional network may help managers to build connections and facilitate fund inflows. With this in mind, we use specification (10) to check if the parental involvement in fund management can explain our results. Results of both tests indicate that our findings are robust to alternative explanations related to educational and parental networks.

Another explanation for our baseline results is that investors pay more attention to salient managerial characteristics such as names, and military managers may simply have names that sound familiar to U.S. investors. Such familiarity can in turn explain the observed heterogeneity in fund flows. Kumar et al. (2015) document significantly lower inflows into

\footnotetext{
${ }^{8}$ Even though previous research consistently finds no significant impact of manager's biological age on fund flows, we also control for age because it is the only managerial attribute that shows statistically significant variation across the two groups in Table 1, Panel B.
} 
funds managed by individuals with foreign-sounding names than into other funds. We implement a machine-learning algorithm from Ye, Han, Hu, Coskun, Liu, Qin, and Skiena (2017) to define foreignness of a manager's name. The results reported in test (9) indicate that both magnitude and significance of the main coefficient estimate remain when we control for foreignness of managers' names.

Recent evidence shows that experience outside the fund management industry gives managers an information advantage, which results in a higher propensity to hold more and to pick better stocks from the area of their expertise (Cici et al. (2018)). Therefore, we check that investors' preference for military-managed funds is neither due to a potentially higher share of defense stocks in total holdings (test (4)) nor affected by the manager's expertise in other industries (test (8)).

Mutual fund investors may be attracted to funds that reinforce their market position and acquire customers by conducting a marketing campaign. Barber, Odean, and Zheng (2005) show that investors tend to purchase funds that draw their attention through marketing or advertising. We therefore control for marketing expenses, which we define as the share of a fund's expenses for marketing (from NSAR-B filings) in total expenses. Indeed, funds with a higher share of marketing expenses seem to attract higher fund flows, but importantly the effect of military experience of mutual fund managers on fund flows remains unchanged in the joint regression specification (11). Additionally, we control for media coverage of fund managers (test (13)), which is important for two reasons: (i) media coverage has been shown to affect net investor flows (Kaniel, Starks, and Vasudevan (2007)), and (ii) military managers may generally have a higher profile in U.S. society. We find that the effect of military background is not attenuated by including the managers' media coverage control.

Next, we exclude index funds from the sample test (14) and control for distribution channels (12). Results for each of these alterations indicate that the coefficient estimate on the Military indicator variable is still statistically significant and economically meaningful. Finally, another concern is that the fund flow effect we uncover in Table 2 may simply be driven by investor preference for military individuals that is unrelated to presumed managerial qualities. If that is the case, we should observe similar military-related flow patterns for index funds. However, results reported in test (15) indicate that the military background effect is not present in the sample of index funds, which renders a simple preference explanation unlikely. 


\subsection{Degree of Involvement in the Military and Fund Flows}

Previous sections suggest a robust link between the military experience of mutual fund managers and fund flows. This suggestion implies that information disclosures about the military background of an active manager influence mutual fund investor decisions. However, both the amount of information revealed and the details about the military experience vary considerably across managers. Some managers in the sample are medal-decorated war veterans, while others only communicate that they served in the military. In this regard, if there is information that draws attention to prolonged military service, heroic achievements, and meritorious service in a combat zone, it may amplify the effect on flows into funds managed by an individual with a military background. To investigate this possibility,

we differentiate managers by their degree of involvement in the military and estimate flow regressions.

Table 4 provides evidence of heterogeneity in fund flow effects across managers with various degrees of military involvement and recognition. The Conflict/Medal indicator variable is coded as one for funds managed by an individual who served a tour of duty in a conflict zone. In total, we identified 66 such funds, with $20 \%$ having managers who received United States Armed Forces awards and decorations, including the Bronze Star Medal, Purple Heart, Combat Action Ribbon, service stars, and so forth. Further, to cover the other extreme of military involvement, we additionally identified 43 funds that are managed by managers who have undergone military training but have never served in the military. In particular, the Military training dummy takes the value of one if a manager graduated from any of the U.S. military schools and academies or voluntarily participated in any type of military training, but never served a period of active duty. The regression setup is similar to that applied in the previous section.

Consistent with the view that partisan investors allocate funds, among other things, based on a fund manager's military background, we find that in both univariate sorting (panel A) and regression analysis (panel B) the Conflict/Medal variable is significantly and positively related to fund flows. Comparing the sample means for funds managed by individuals who served a tour of duty and for peer funds with managers who do not have such background, we find a remarkable difference of 21.9 annualized percentage points (t-statistic of 3.39) in net fund flow between the two groups. The coefficient on the interaction term Military $\times$ Conflict $/$ Medal is positive and significant $($ coefficient $=0.005$, t-stat. $=2.06$ ). The magnitude compares favorably to the estimates of the Military dummy, indicating that managers who present themselves as war veterans attract more flows in comparison to those who just disclose that they served in the military. In contrast, Military training produces negative and not statistically significant estimates across all specifications. By construction, 
this variable largely captures military-related education of fund managers. In this, our results are consistent with prior research that documents no fund flow effects of managers' education (Niessen-Ruenzi and Ruenzi (2018)).

\subsection{Salience of Information and Fund Flows}

Previous research suggests that cosmetic effects irrationally influence investor decisions. Hirshleifer (2001) suggests that even irrelevant, redundant, or outdated news affects security prices if presented saliently. Cooper, Dimitrov, and Rau (2001) document stock price reactions to timely firm name changes. Similarly, asset allocation decisions of mutual fund investors are influenced by cosmetic features of funds and fund managers, for instance, by style-related fund name changes (Cooper et al. (2005)), fund manager name disclosures (Kumar et al. (2015)), or other salient attention-grabbing information (Barber et al. (2005)). In this section, we explore if the observed relation between military experience and fund flows differs with respect to the salience of information investors are exposed to.

The investor's level of effort to obtain information on the managers' military background varies by manager. Therefore, we differentiate managers by the source that discloses the relevant information. Table 5 provides evidence on the fund flow effect for different means of information disclosure. The first group, Investment media, includes cases in which information on prior military experience is disclosed through investment media sources, namely, Morningstar and Bloomberg. The second group, Personal disclosures, covers cases in which this information is not available in investment outlets but can be found on fund company websites or professional networks, such as LinkedIn. The third group, Other sources, includes cases in which military background information is only disclosed via major or regional newspapers and other alternative media outlets. This categorization differentiates the investor's effort to obtain information. Correspondingly, we suggest that the probability of the investor becoming aware of the manager's biographical facts is higher for the first two groups relative to the third group.

Additionally, we identify 37 funds with ex-military managers that are not included in our main sample since information on their military service was not publicly available during the period of active fund management. In these cases, the information only becomes available in managers' obituaries. The Post-mortem placebo group in Table 5 covers managers for whom military affiliation is disclosed only in obituary notices after their death and not prior to it. As such, this last group serves as a placebo test.

The average flow differences between military and nonmilitary managers indicate a sharp distinction between the groups. Mutual funds with a manager whose prior involvement in 
the military is disclosed via investment media have $17.2 \%$ higher annualized fund flows ( $\mathrm{t}$ statistic of 3.52). Managers with slightly more salient disclosures attract $22.1 \%$ p.a. higher fund flows per annum (t-statistic of 6.27). In contrast, revealing this information through other sources that are less prominent has no effect on fund flows. The magnitudes of the monthly flow regression coefficient estimates favorably support the notion that the fund flow effect is more pronounced when investors are exposed to salient, attention-grabbing information. As expected, results from the placebo group of funds reveal no fund flow effect, which further supports this notion.

Thus far, the analysis has focused only on single-managed funds and excluded all teammanaged funds. Next, we examine whether funds managed by teams that include individuals with prior military experience are able to attract more fund flows relative to funds that do not have such managers in their teams. For this purpose, we additionally identify 159 funds with at least one military manager who is part of the team and re-estimate the baseline regressions using the sample of team-managed funds. The regression setup is otherwise similar.

The fund flow effect of a manager's military background is suppressed in team-managed funds. Table 6 relates monthly net fund flows to a Military team dummy variable that equals one if the fund is managed in a given month by a team that includes a manager with a military background and zero otherwise. In columns (1) and (2), we present the estimates of regressions after including various controls along with segment and time fixed effects. The coefficient on the main variable of interest is positive but not statistically or economically significant (in the specification with lagged fund flows). Adding the share of military managers in a team and several interaction terms with sources of information disclosure neither changes the baseline evidence nor reveals new results. The table's main message is that no significant flow effect is present between funds with military managers in teams and funds managed by nonmilitary teams. This finding is consistent with the supposition that a manager's personal background information is much less salient and eyecatching in team-managed funds relative to single-managed funds.

\section{Evidence of Military-Based Partisanship}

This section presents evidence that the observed relationship between a manager's military background and fund flows can be attributed to the military-associated partisanship that affects asset allocation decisions of mutual fund investors. 


\subsection{Fund Flows and Social Attitudes toward the Military}

Figure 1 provides illustrative evidence on how social attitudes toward the military institution and military-related partisanship affect the decisions of U.S. mutual fund investors. This example suggests that investors' buying and selling behavior toward mutual funds managed by individuals with a military background positively correlates with the level of confidence and satisfaction in the U.S. military. In other words, investors tend to allocate more capital to military-managed funds when confidence in the military is high, while the difference in fund flows between military- and nonmilitary-managed funds is less pronounced in times of low confidence.

To provide formal statistical evidence on the link between partisan mutual fund investor decisions and a manager's military experience, we conduct three additional tests. First, we repeat regressions of monthly net fund flows on the military indicator for periods of high and low levels of confidence in the military, classified based on the median level of the Gallup Poll's confidence in the military index from Figure 1. Second, we collect National Instant Criminal Background Check System (NICS) data on purchases of firearms, provided by the Federal Bureau of Investigation, and consider the information as an alternative proxy for nationwide confidence in the military institution. Third, we use four prominent militaryrelated scandals and two successful high-profile military operations as natural experiments to provide further support for a trust-based explanation of our findings.

Table 7, Panel A first reports evidence on the fund flow effect for periods of low and high confidence in the military. The results reported in columns (1) and (2) show that in both cases the Military dummy is significantly positively related to fund flows, with estimates of 0.002 (t-statistic of 1.83) and 0.003 (t-statistic of 3.07) for low and high confidence periods, respectively. The magnitudes of the coefficients favorably support the notion that the fund flow effect is more pronounced when confidence in the military is relatively high.

Next, Table 7, Panel A relates an alternative measure of confidence in the military (i.e., the change in purchases of firearms) to monthly net fund flows. Studies in psychology and political science document a strong link between the perception of insecurity and associated trust in public institutions. Blanco and Ruiz (2013) show that an individual's perception of insecurity is negatively related to satisfaction in the political regime and confidence (trust) in public institutions, including the military. ${ }^{9}$ In the context of Figure 1, when the confidence in the military institution is low, the aggregate level of perceived insecurity is likely to be high and vice versa. Alongside, Diener and Kerber (1979), Cao, Cullen, and Link (1997),

\footnotetext{
${ }^{9}$ Other studies in political science suggest that trust in public (political) institutions is positively related to partisan strength (Hooghe and Oser (2017)), while an apparent distrust in politics can result in unwillingness to publicly declare a partisan identity despite attitudes to the contrary (Petrocik (2009)).
} 
and Carlson (2012), among others, show that U.S. citizens perceive firearm purchases as a potential complex response to distrust in public institutions and anxieties regarding insecurity. ${ }^{10}$ Therefore, we consider purchases of firearms as an alternative measure of the confidence in the military. ${ }^{11}$ The results reported in column (3) show that the coefficient on the interaction term between Firearm checks (NICS) and the Military dummy is negative and significant (coefficient $=-0.003$, t-stat. $=-2.70$ ). This outcome indicates that fund flows are lower for military-managed funds when the nationwide perceived insecurity is high and, correspondingly, the confidence in the military institution is low.

In specifications (4) and (5), we split the sample into periods of relatively high and low levels of insecurity, respectively. Results in column (4) suggest that during periods of positive change in firearm purchases, when the aggregate level of perceived insecurity is likely to be high, funds managed by military-experienced individuals tend to draw less pronounced investor interest and have difficulties in attracting fund flows. In contrast, results for the periods of negative changes in firearm purchases, in column (5), show that the estimate on the Military dummy is positive (coefficient $=0.004$ ), statistically significant at the $1 \%$ level, and much higher in magnitude relative to its counterpart in column (4). This outcome suggests that periods of relatively low perceived insecurity and high level of trust in public institutions are associated with distinct investors' partisan attitudes toward military-managed mutual funds.

In order to provide further support for a trust-based explanation of our findings, we next use six natural experiments that occurred over the sample period of our study. Specifically, we consider the following events: the Tailhook scandal; the U.S. Naval Academy's cheating scandal; the Abu Ghraib scandal; the Lackland Air Force Base sex scandal; the success of the Operation Red Dawn (capture of Saddam Hussein); and the success of the Operation Neptune Spear (death of Osama bin Laden). The first four events are widely considered among the biggest military-related scandals, while the last two are among the most successful missions of the U.S. military in history. Importantly, in these tests we exploit the fact that each of these events plausibly generated an exogenous shock to the trust in the military and the strength of military-associated partisanship in the U.S.

Table 7, Panel B presents the results of natural experiments and provides evidence on flows into funds managed by military-experienced individuals following the aforementioned events. Specifically, in each case we interact the Military dummy with indicator variables

\footnotetext{
${ }^{10}$ Notably, the aforementioned papers do not explicitly state which public institution failures (the police or the military) trigger gun purchases the most; however, in all these papers, the need for protection and the perception of insecurity are found to be the main psychological reasons for firearm purchases.

${ }^{11}$ Importantly, according to the Gallup survey data, $34 \%$ to $51 \%$ of U.S. households had a gun in possession over the sample period of our study.
} 
that cover three months following a given event. The coefficient estimates of the interaction terms reveal that military managers experience significantly lower fund flows following the scandals that likely had a negative effect on nationwide trust in the military. The estimates show that military-managed funds experience an abnormal decline in fund flows after the Tailhook scandal (coefficient $=-0.004$ ), the Naval Academy's cheating scandal (coefficient = -0.006), the Abu Ghraib scandal (coefficient $=-0.006$ ), and the Lackland Air Force Base sex scandal (coefficient $=-0.010$ ). In contrast, results indicate that military managers experience an increase in fund flows following the two high-profile successful military operations, with coefficient estimates of 0.009 (t-statistic of 1.97) and 0.014 (t-statistic of 2.58) for the Red Dawn and the Neptune Spear missions, respectively.

Overall, this evidence is consistent with the view that military-associated partisanship exists among mutual fund investors, and it provides additional support for the conjecture of trust-based investor asset allocation behavior toward military-managed mutual funds.

\subsection{Fund Flows and Managerial Turnover}

Mutual fund managers come and go. It has long been recognized that a fund manager change is one of the most informative occurrences in a mutual fund's lifetime. Khorana (1996) shows that on average the replacement of a mutual fund manager leads to subsequent underperformance. Chevalier and Ellison (1999) build on this evidence and, among other findings, indicate the potential inflow-related benefits of replacing a poor-performing manager. In a theoretical model, Dangl, Wu, and Zechner (2006) suggest that management replacements may be accompanied by capital inflows, depending on the tenure of the manager that is being replaced. Importantly, regardless of the reason why the change occurred, such an event draws the investors' attention and puts an incoming manager in the spotlight, providing a perfect setting for exploring the existence of military-based partisanship among mutual fund investors.

Therefore, we investigate the fund flow dynamics around the dates of managerial turnover. In particular, we examine whether funds that shift to managers with a military background subsequently exhibit different fund flows relative to funds that employ nonmilitary fund managers. We only consider instances when the incoming manager single-handedly manages the fund, and overlapping periods of management are excluded.

Figure 2 illustrates an increase in average monthly net inflows into both types of funds after the management change. Noteworthy, flows into funds managed by individuals with a military background are substantially higher than the ones into funds with nonmilitary managers. For both groups, fund inflows reach their maximum in the month of the manager 
change. In the subset of military-managed funds, inflows remain high for all the subsequent months, while funds managed by nonmilitary individuals experience an inflow decline to around the pre-turnover level. The differences in net inflows between the two groups over the 10 months following the managerial turnover are economically significant. Funds managed by individuals with military experience receive between $6.6 \%$ and $38.4 \%$ higher annualized fund flows.

Figure 3 provides additional evidence by presenting average flows for the two groups around the dates when a single manager leaves the fund. By contrast, we observe an outflow from funds previously managed by individuals with a military background during the month of managerial turnover, while flows into nonmilitary funds are essentially unaffected. The month in which the manager change occurs is the only period in the 20 months surrounding it that has an actual outflow. The difference amounts to a sizable -12.0 annualized percentage points.

While the above descriptive tests present some evidence of heterogeneity in fund flows between the two groups around the dates of managerial turnover, one can argue that the observed inflows are induced by the change in management itself rather than investor militaryrelated partisanship affecting the asset allocation decision. That is, a fund company can choose to heavily advertise that it has replaced a manager, drawing attention to the superiority of an incoming manager relative to the manager that is being replaced. Jain and $\mathrm{Wu}$ (2000) show that advertised funds are indeed able to attract significantly higher inflows.

To alleviate this concern and address possible endogeneity between the two groups, we implement a difference-in-differences approach by comparing changes in fund flows around the dates of managerial turnover of funds with military management (treatment funds) to changes in fund flows of funds with nonmilitary managers (control funds). In this test, we restrict the sample to funds that only had one change from team to solo management over the sample period of our study, and we use the following specification:

$$
F_{t}^{i}=\alpha_{0}+\beta_{1} \text { Treat }_{i}+\beta_{2}\left(\text { Treat }_{i} \times \text { Post }_{t}\right)+\gamma X+\eta_{j}+\tau_{t}+\epsilon_{i, t}
$$

where $F_{t}^{i}$ is the net fund inflow of fund $i$ as in (1); Treat $t_{i}$ is an indicator for funds that were ever managed by individuals with a military background and affected by the managerial turnover; Post $_{t}$ is an indicator variable that equals one for months of solo management period and zero otherwise; $X$ is a vector of control variables; and, $\eta_{j}$ and $\tau_{t}$ are segment and period fixed effects, respectively. In the above model, the treatment occurs at different times and the full set of period dummies is included. Our main results are unaffected if we standardize the treatment periods. The primary coefficient of interest in the above specification is the coefficient $\beta_{2}$ on the difference-in-differences estimator, Treat $_{i} \times$ Post $_{t}$, which indicates if the 
average change in fund flows from before the change to solo management to afterward was different in the two groups.

Table 8 reports the results for a difference-in-differences estimation in regression (2). The coefficients on the interaction, Treat $_{i} \times$ Post $_{t}$, are uniformly statistically significant regardless of the model specification. Coefficients equal 0.006 (t-stat. $=7.24$ ) and 0.002 (t-stat. $=2.48$ in columns (1) and (2), respectively. In column (1), we report the estimates after including just the segment and period fixed effects and no control variables, and in column (2), we introduce a set of control variables detailed in Section 3. These findings are also economically meaningful; all else being equal, the coefficient estimates imply that individuals with a military background receive up to 6.7 annualized percentage points higher net fund inflows than others. Importantly, we find that in both specifications, Treat indica- $^{-}$ tor reports small and insignificant coefficients, suggesting that the treatment and control funds exhibit parallel movements in their fund flow outcomes in the absence of the treatment shock. The pre-change parallel trend in fund flows between the two groups is further confirmed in columns (3) and (5), where we augment the difference-in-differences design with interaction terms of the Treat $_{i}$ variable with periods preceding the managerial change. Findings indicate that no statistical difference in the outcome variable exists prior to the management rotation. In contrast, the coefficients on the interaction terms of the Treat variable with post-change periods in column (4) and (5) suggest that the net fund inflows increase following the induction of military-experienced managers. The fund flow effect is the most pronounced in the first month of active management $\left(\right.$ Treat $_{i} \times$ Post $)$, indicating that managers with a military background receive $5.7 \%$ higher inflows during the first month of active management relative to other managers. The difference in fund flows between the two groups is persistent, however, it slightly weakens over time.

The evidence of this section is hard to reconcile with an alternative fundamental-based explanation and supports the notion that military-induced trust in the manager affects investors' buying and selling behavior toward mutual funds.

\subsection{A Closer Look at the Flow-Performance Relationship of Military-Managed Funds}

Investors are ultimately concerned about performance outcomes. Thus, in this section we investigate if the observed flow patterns are also reflected in the distribution of performance realizations of mutual funds. Specifically, we explore whether an investor's willingness to allocate more capital to military-managed funds than to other funds persists after both 
extreme positive and negative performance months. ${ }^{12}$ Given our previous results, we expect that managers with a military background attract relatively more flows regardless of the extremity of performance outcomes.

Table 9 relates monthly net fund flows to the performance of mutual funds. Column (1) shows that the coefficients on the main variable of interest, the interaction term Military $\times$ Performance rank, is positive and statistically significant (coefficient $=0.010$, t-statistic of 6.10). This outcome suggests that fund flows are higher for those military-managed funds that are at the top of the performance ranking. In other words, the observed differences in fund flows between the two groups can be attributed to significantly higher capital inflows into mutual funds with military-experienced managers following the months of outperformance.

Barber et al. (2005) show that the fund flow-performance relationship is in fact nonlinear. Therefore, the remaining specifications in Table 9 estimate a quadratic performance-flow relationship. The coefficient estimates in columns (3) and (4) reveal that the interaction term of the dummy for military managers with squared past performance is uniformly statistically significant and positive, while the interactions with linear past performance are negative, emphasizing the non-linearity of the flow-performance relationship. This outcome indicates that the difference between military and nonmilitary-managed funds is especially large for extreme performance realizations. In particular, the results suggest that military-managed mutual funds not only have higher fund flows following extremely good performance, but also following months of very poor return realizations relative to their nonmilitary-managed counterparts. These findings are largely unaffected by the inclusion of various fixed effects in the regressions.

\subsection{Microlevel evidence from an online experiment}

The key assumption of this paper is that the majority of investors are likely to be sensitive to fund manager background information when making investment decisions. To verify this assumption, we perform an online survey among U.S. mutual fund investors via Amazon Mechanical Turk (AMT). Specifically, we ask 200 mutual fund investors whether they knew and considered the fund manager's profile at the time of investing. Sixty-seven percent of the respondents reply in the affirmative.

Results of Section 3.3 and Section 3.4 suggest that investors are likely to base their purchase decisions partially on a manager's personal background information and that military-

\footnotetext{
${ }^{12}$ We rely on scaled performance ranks to gauge the performance outcomes. Performance rank represents the position of the fund's monthly return relative to all other funds in the same market segment (based on Morningstar style boxes).
} 
associated partisanship exists among mutual fund investors. However empirically controlling for all other potential drivers of fund flows in our setting is not possible. Thus, we conduct an online experiment via AMT to further investigate the relation between managers' military affiliation and fund flows. The procedure allows us (i) to control for fund characteristics, so we can rule out statistical discrimination-related explanations of our results, and (ii) to examine the impact of investor characteristics on investment decisions, in contrast to the previous empirical analysis focusing on aggregate investor behavior at the fund level. As in Kumar et al. (2015), we recruit individuals at AMT to complete a hypothetical fund investment task in which they are required to split an investment of 100 dollars between two funds, which are labeled "fund A" and "fund B". ${ }^{13}$

Our investment experiment is conducted with 804 individuals who self-report that they are located in the United States and own mutual funds. We provide subjects with information about each fund A and B, including fund segment, size, inception date, expense ratio, annual turnover, the top five holdings, past performance, a short description of the investment objective, and a short profile describing the fund manager. ${ }^{14}$ The experiment lasts four rounds. In each round, participants split 100 dollars between two funds. To avoid subjects learning that the experiment is about military affiliation and to ensure that our experimental results are robust, one of the two funds is managed by an ex-military manager only in rounds 2 and 4, while neither fund is managed by such individual in rounds 1 and 3. In round 2 both funds have very similar fund attributes, but in round 4 we assign negative past returns to fund A.

Next, subjects are randomly assigned to one of two groups. The key feature of the experiment is that in rounds 2 and 4 half of the individuals observe that fund $\mathrm{A}$ is managed by an ex-military fund manager, whereas fund B is managed by a nonmilitary manager. In rounds 1 and 3, individuals of both groups observe only nonmilitary-managed funds. Hence, any difference in investment behavior between the two groups can solely be attributed to the fund manager's military background.

Table 10 presents the results of this experiment. Table 10, Panel A shows that AMT participants invest 3.36 dollars more in the fund A when it has a manager with military experience. Results of both rounds 2 and 4 uniformly suggest that subjects allocate more money to the fund with an ex-military manager. Moreover, the inclination toward militaryexperienced managers persists when subjects are confronted with negative past returns of the military-managed fund (round 4), corroborating the evidence in Section 4.3 In contrast,

\footnotetext{
${ }^{13}$ We thank Alexandra Niessen-Ruenzi for providing us with the experimental setup.

${ }^{14}$ Each of the fund profiles represent a hypothetical diversified equity mutual fund singlehandedly run by a male manager with an American-sounding name, e.g. "Charles Miller."
} 
when we specify no prior military affiliation to managers of both funds (untabulated placebo rounds 1 and 3), we find no significant difference in asset allocation.

Results reported in Table 10, Panel B provide further evidence on the relation between fund manager military background and fund flows, while focusing on specific investor characteristics. ${ }^{15}$ In columns (2) and (3), we investigate subsamples of subjects by party affiliation (i.e., Democrats and Republicans). The participants self-report party identification. We find the military background effect on investment allocation decisions in both subsamples, with the coefficients of 4.32 (t-stat of 1.72) for the Democrats and 4.53 (t-stat of 1.89) for the Republicans. This outcome is consistent with the Gallup Poll survey evidence that U.S. citizens, independent of their party affiliation, perceive military-affiliated individuals as trustworthy. In column (4), we use several additional interaction terms and show that our results are more pronounced among older investors.

We find that the effect of a fund manager's military background on the amount invested in a fund is economically sizable, but lower in magnitude than the effect that we document in our CRSP/Morningstar sample. ${ }^{16}$ This result makes intuitive sense because participants are likely to pay less attention to a manager's profile when they do not have their own money at stake. Further, in our experimental setting, the military background effect is lower in magnitude compared to the relatively more salient effects related to gender and manager name documented in Kumar et al. (2015) and Niessen-Ruenzi and Ruenzi (2018).

Overall, the results of this section further confirm the previously observed relation between managerial military background and fund flows and suggest that the majority of investors consider manager background information when making their investment decisions.

\section{Additional Tests}

\subsection{Military Background and Window Dressing}

Previous research suggests that investors likely prefer managers that require less monitoring (Gennaioli et al. (2015)). In the context of our paper, investors may view managers' military background as an indicator of potentially more compliant and ethical behavior that reduces perceived investment risk. Consequently, an intriguing question is whether exmilitary managers live up to investors' expectations and actually act more ethically relative to other managers.

\footnotetext{
${ }^{15}$ Additionally, when we exclude AMT participants who spent less than two minutes on the experiment from our sample, we find that the observed effect strengthens with participation time showing that our results are not induced by AMT workers who did not take the task seriously.

${ }^{16}$ To the best of our knowledge, no major military-related events occured around the dates of the experiment (August 2019) that could negatively affect our results.
} 
To answer this question, we examine whether managers with military experience are less likely to engage in window dressing activities relative to nonmilitary managers. Solomon, Soltes, and Sosyura (2014) argue that investors pay attention to portfolio holdings reports and, among other things, evaluate managers based on their particular stock picks. Consequently, some fund managers window dress their portfolios (remove poorly performing holdings) before filing dates in an attempt to deceive investors. These practices are generally viewed as unethical at best and may even be illegal (Lakonishok, Shleifer, Thaler, and Vishny (1991); Patel and Sarkissian (2013)). Following Agarwal, Gay, and Ling (2014), we rely on two measures of window dressing, namely Rank Gap and Backward Holding Return Gap (BHRG). Rank Gap is a relative window dressing measure that captures inconsistency between a fund's performance rank and the two ranks based on winner and loser stocks proportions in the reported holdings. BHRG is the difference between the net return of a hypothetical portfolio that is based on the fund's reported holdings and the fund's actual return. The time period is from 2003 - the year from which funds were required to file holdings information on a quarterly basis - to 2017.

Table 11 relates a manager's military background to the two window dressing measures. The coefficients on the military dummy variable are uniformly negative and statistically significant. This result suggests that managers with a military background engage in significantly less window dressing relative to their nonmilitary peers. In other words, they are less likely to remove poorly performing holdings before filing dates. Moreover, we observe this pattern regardless of whether the fund is in the top or bottom quintile of performance within its segment prior to the holdings report. While acknowledging the existence of other potential explanations, we suggest that these findings point to the conclusion that ex-military managers demonstrate more compliant and ethical behavior relative to others. Additional cross-database screening for evidence of managerial misconduct of various kinds revealed no instances of ex-military managers in our sample being involved in any illegal activity. ${ }^{17}$

\subsection{Matched Sample Analysis}

To guard against the possibility of a spurious relationship between military background and fund flows caused by sample-specific unobserved characteristics of funds or managers, we perform two different matching procedures. In doing so, we attempt to bring the sample properties of the control (nonmilitary) funds as close as possible to the military-managed funds. Thus, we assume that if the observed characteristics of the two groups of funds are

\footnotetext{
${ }^{17}$ Similar to Egan, Matvos, and Seru (2019), we collect data from FINRA BrokerCheck. The data include all disciplinary events, including civil, criminal, and regulatory events, and disclosed investigations for all registered brokers and the set of investment advisers who are also registered as brokers.
} 
identical, then the unobserved attributes are likely to be similar as well.

Table 12 presents results from a matched sample analysis. We use two approaches to match funds. First, for each observation with a military-experienced manager, we search for nonmilitary-managed twin funds with similar fund or managerial characteristics. In doing so, we require values of the non-categorical variables for nonmilitary fund in a given month to be within $5 \%$ of those of a military-managed fund. The set of characteristics includes fund's segment, family, size, age, share of marketing expenses, performance, and manager's gender, biological age, industry tenure, and foreignness of a name. In all cases, we require the matching attributes to be from the same month and drop all other nonmilitary funds' observations that do not have a matching military counterpart in a given month. Second, we perform the propensity score nearest neighborhood matching procedure on the set of fund characteristics, including fund performance, fund size, expense ratio, turnover, fund age, and lagged fund flows. Then we re-estimate the baseline flow regression (column 3 of Table 2) based on the resulting matched samples.

Results of the matched sample analysis show a uniformly positive and statistically significant impact of the Military dummy on fund flows. The magnitudes of the coefficients in specifications (2) to (16) compare favorably to the estimate in (1), suggesting that in 13 out of 15 cases confining the sample to better matches in terms of observable characteristics results in a similar or more pronounced effect of manager's military background on fund flows. Moreover, when we match funds based on fund segment and manager gender, and

additionally require the matching funds to be in the same fund family (in (5)) or to have very similar returns (in (10)), and when we perform propensity score matching (in (12) to (16)), the sample size shrinks significantly, but statistical significance remains. This evidence indicates that restricting the analysis to more similar funds does not alter the baseline results on the military background effect, which means that an unobservable variable explanation of our results is unlikely.

\subsection{Alternative Measures of Fund Flows}

Thus far, the main dependent variable of this paper has been relative net fund flows, that is, the percentage change in total assets under management, net of internal growth. However, recent studies question the reliability of the relative fund flow measure due to apparent violations of additive constraint. Spiegel and Zhang (2013), for instance, suggest using a fund's market share instead. Therefore, in this section, we test two alternative specifications of the fund flow measure, namely, the absolute dollar flows and the change of a fund's market (segment) share as dependent variables. 
Table 13 reports results for the two alternatively specified fund flow measures. Our findings confirm the existence of a positive impact of the managerial military experience on fund flows for both measures. In columns (1) and (2), coefficient estimates of the Military dummy in all-inclusive flow regressions with the absolute dollar flows as the dependent variable are still positive and significant. Results are also economically meaningful, with military managers receiving $\$ 3.3$ million higher monthly fund flows on average relative to their nonmilitary counterparts. Further, results of the quantile regression with the change of a fund's segment share as the dependent variable also reveal that the coefficient estimate of the main variable of interest, the Military dummy, is positive and significant at the $1 \%$ level (t-statistic of 5.15). Thus, the inference that a military background of mutual fund managers affects fund flows remains unchanged.

\subsection{Fund Performance and Persistence}

Next, we examine whether the observed relationship between military background and fund flows arises from the possibility that investors rationally prefer managers with a military background due to their potential superiority in generating risk-adjusted performance or higher performance persistence. Table 14, Panel A, reports the risk-adjusted alpha estimates of a hypothetical long-short portfolio that assumes a long position in all military-managed funds and a short position in all nonmilitary-managed funds in our sample. Regardless of the factor model, the difference portfolio does not deliver any economically or statistically significant risk-adjusted alphas. All alpha estimates, based on either net or gross performance, are close to zero and far from being statistically significant (t-statistics ranging from 0.38 to 1.50$)$. This suggests that significant performance differences between military and nonmilitary managers are unlikely. As an additional test, we compare fund performance persistence of military and nonmilitary managers. Performance persistence is computed as the average time-series standard deviation of monthly performance ranks. The results of Table 14, Panel B reveal no statistically significant difference between the two groups, indicating that military managers do not deliver more stable performance relative to other managers.

The evidence of this section suggests that investor inclination toward military-managed funds is unlikely to be associated with rational performance-chasing investor behavior. Rather, it provides additional support to the notion that trust in the manager induced by that individual's military background affects investors' buying and selling behavior toward mutual funds. 


\subsection{Potential Equilibrium Outcomes of Hiring Ex-Military Managers}

Our findings suggest that fund management companies are likely to benefit from hiring managers with a military background because they are associated with relatively higher fund flows. However, taking into account the advantages of hiring ex-military individuals, an important question remains: Why then are most mutual funds not managed by individuals with military experience?

A potential answer to this question is that the supply of qualified military-experienced individuals may be too low to meet the increasing demand for mutual fund managers over the sample period of our study. Figure 4A plots the share of ex-military fund managers and education level of veterans by birth cohort, illustrating the shift in educational attainment of military personnel. This evidence suggests that in the first part of the twentieth century, the likelihood of highly educated individuals serving in the military was higher relative to all other men in the population. Perhaps, among other things, this finding may be related to the fact that prior to 1951 potential military inductees were not permitted to postpone service to attend college. ${ }^{18}$ Following the change in the selection process, the proportion of men with college degrees in the military substantially decreased. Consequently, the share of ex-military personnel among mutual fund managers followed a similar path and remained low from the mid-1950s cohorts onward. Thus, the decreased supply of highly educated military-experienced individuals is likely to be inadequate to meet the demand for fund managers, illustrated in Figure 4B by the steadily declining share of fund managers with a military background among all managers over the sample period.

Several other potential reasons exit for why fund management companies do not widely employ military-experienced fund managers. One possibility is that they may simply be unaware of the flow effect that we uncover in this paper. However, we observe that within our data set, the vast majority of fund companies reveal general background about their active managers through easily accessible media sources. In addition, the results of Section 3.4 indicate that fund companies have fund flow benefits associated with disclosing information through such information outlets, suggesting that most of the fund management companies are likely to act strategically in revealing information about a manager's military background. Another possibility is that fund companies are reluctant to employ ex-military managers because these managers perform worse than others. However, we find that managers with a military background do not exhibit significantly different skills or managerial traits relative to other managers, and if anything, they tend to be more ethical. Overall, we find no supportive evidence for these alternative mechanisms. We acknowledge that other

\footnotetext{
${ }^{18}$ For more information on other potential reasons for the observed differences in educational attainment of military personnel across various cohorts see Bound and Turner (2002).
} 
equilibrium mechanisms that we are not able to address in our setting are possible (e.g., higher compensation paid to managers with military experience).

\section{Conclusions}

In this paper, we investigate whether biographical characteristics of mutual fund managers, specifically prior engagement in the military, influence investor asset allocation decisions. We suggest that distinct trust-building attributes of fund managers with prior military experience result in investors perceiving them as money guardians with military-associated qualities. Thus, investors are more likely to allocate capital to funds managed by militaryexperienced individuals, even when these managers do not exhibit superior investment skill compared with their nonmilitary peers. We find that mutual funds with military-experienced managers have annualized net fund flows that are 10.6 percentage points higher and grow by up to $6.5 \%$ faster per annum relative to comparable funds run by managers who do not have such a background. Military managers' superiority in competing for investor funds cannot be explained by fund or managerial attributes, including performance, and it is robust to several alternative explanations. Additionally, we find that the content and salience of disclosures about the military background also influence investor decisions; that is, the fund flow effect is more pronounced when investors are exposed to salient, accentuated information.

Although we observe no evidence of rational statistical reasons for such investor decisions, results from several tests provide support for trust-mediated allocation of assets. We find that investors' buying and selling behavior toward military-managed funds is related to nationwide confidence in the military, ratified by distinct investors' partisan attitudes toward these funds during the episodes of heightened trust. Consistent with this finding, we observe that ex-military managers experience significantly lower fund flows following the exogenous events of military-related scandals that have adversely affected nationwide trust in the military. Further, we find that military managers have higher fund inflows relative to their nonmilitary counterparts following both extremely good and poor performance. The difference-in-differences analysis around the dates of managerial turnover reveals that, even without any other fundamental events and all else being equal, incoming managers with a military background receive significantly higher net fund flows relative to other managers. In an experimental setting in which we randomly assign military background to managers and eliminate the possibility for rational choice explanations, we find that subjects invest significantly more money in a fund when it has an managed by an ex-military manager. Last, using investor-level information, we observe that military-induced asset allocation is unaffected by investor political party identification but is more pronounced among older 
investors.

Taken together, the findings of this paper suggest that military-associated trust-building attributes of fund managers influence mutual fund investor decisions. The empirical findings of this paper provide support to portfolio management delegation theories, particularly those emphasizing the role of trust, and can be interpreted under the description of trust-mediated fund allocation offered in them. Future research could further investigate the causes and effects of trust in the asset management industry. One direction for future research would be an exploration of the potential for trust-induced investor decision-making related to other economic agents (e.g., corporate executives, financial analysts, and hedge fund managers). Finally, it might be useful to explore other managerial characteristics that could potentially foster investor trust and affect investor purchase decisions. 


\section{Appendix A. Variable Description}

Table A.1. Descriptions of Main Variables and Sources.

This table provides descriptions and sources of variables used in our study. The following abbreviations are used: CRSP - CRSP Survivorship Bias Free Mutual Fund Database; MS - Morningstar Direct Database; BL - Bloomberg; MQ - Marquis Who's Who database; FINRA - BrokerCheck; LI - LinkedIn, SEC - SEC filings, NSAR-B filings; INT - Intelius database; GI - GI Search engine; ANC - Ancestry.com; LEG - Legacy.com; FW - Fund company websites; LN - LexisNexis; NP Newspapers.com; Gallup - The Gallup polls; FBI - Federal Bureau of Investigation NICS database; AE - Authors' estimations; MC - Manually collected.

\begin{tabular}{|c|c|c|}
\hline Variables & Description & Source \\
\hline \multicolumn{3}{|c|}{ Panel A: Dependent Variables } \\
\hline Fund flows & $\begin{array}{l}\text { Monthly net percentage mutual fund flows, com- } \\
\text { puted as }\left(T N A_{t}^{i}-T N A_{t-1}^{i}\left(1+r_{t}^{i}\right)\right) / T N A_{t-1}^{i} \text {, } \\
\text { where } T N A_{t}^{i} \text { is the fund } i \text { 's total net assets in } \\
\text { month } t \text { and } r_{t}^{i} \text { stands for the net return in month } \\
t \text {. }\end{array}$ & CRSP, AE \\
\hline Absolute dollar flows & $\begin{array}{l}\text { Monthly absolute dollar value of fund flows, com- } \\
\text { puted as } T N A_{t}^{i}-T N A_{t-1}^{i}\left(1+r_{t}^{i}\right) \text {, where } T N A_{t}^{i} \\
\text { is the fund } i \text { 's total net assets in month } t \text { and } r_{t}^{i} \\
\text { stands for the net return in month } t \text {. }\end{array}$ & CRSP, AE \\
\hline $\begin{array}{l}\text { Change of a fund's mar- } \\
\text { ket (segment) share }\end{array}$ & $\begin{array}{l}\text { A fund's segment share in a given month divided } \\
\text { by fund's segment share in the previous month, } \\
\text { where the segment share is a fraction of a fund's } \\
\text { TNA in the average segment TNA. }\end{array}$ & CRSP, AE \\
\hline \multicolumn{3}{|c|}{ Panel B: Main Independent Variables } \\
\hline Military & $\begin{array}{l}\text { Dummy variable equal to } 1 \text { if a fund is single- } \\
\text { managed by an individual with a military back- } \\
\text { ground in a given month and } 0 \text { if an active man- } \\
\text { ager does not have a military background. }\end{array}$ & $\begin{array}{l}\text { MS, BL, MQ, } \\
\text { FW, LI, SEC, GI, } \\
\text { LN, NP, AE, MC }\end{array}$ \\
\hline Military team & $\begin{array}{l}\text { Dummy variable equal to } 1 \text { if a fund management } \\
\text { team includes a manager with prior military back- } \\
\text { ground in a given month and } 0 \text { otherwise. }\end{array}$ & $\begin{array}{l}\text { MS, BL, MQ, } \\
\text { FW, LI, SEC, GI, } \\
\text { LN, NP, AE, MC }\end{array}$ \\
\hline Conflict/Medal & $\begin{array}{l}\text { Dummy variable equal to } 1 \text { if a fund is single- } \\
\text { managed by an individual who served a tour of } \\
\text { duty in a conflict zone and } 0 \text { otherwise. }\end{array}$ & $\begin{array}{l}\text { MS, BL, MQ, } \\
\text { FW, LI, SEC, GI, } \\
\text { LN, NP, AE, MC }\end{array}$ \\
\hline Military training & $\begin{array}{l}\text { Dummy variable equal to } 1 \text { if a manager has never } \\
\text { served in the military but has graduated from any } \\
\text { of the U.S. military schools and academies or vol- } \\
\text { untary participated in any type of military train- } \\
\text { ing and } 0 \text { otherwise. Based on additionally col- } \\
\text { lected data. }\end{array}$ & $\begin{array}{l}\text { MS, BL, MQ, } \\
\text { FW, LI, SEC, GI, } \\
\text { LN, NP, AE, MC }\end{array}$ \\
\hline
\end{tabular}

Continued on next page... 
Table A.1 - continued from previous page.

\begin{tabular}{|c|c|c|}
\hline Variables & Description & Source \\
\hline \multicolumn{3}{|l|}{ Panel C: Fund Variables } \\
\hline Military team share & $\begin{array}{l}\text { Share of military-experienced managers in a fund } \\
\text { management team. }\end{array}$ & $\begin{array}{l}\text { MS, BL, MQ, } \\
\text { FW, LI, SEC, GI, } \\
\text { LN, NP, AE, MC }\end{array}$ \\
\hline Returns (raw) & A fund's monthly raw net return. & CRSP \\
\hline Performance rank & $\begin{array}{l}\text { Performance rank based on a fund's monthly re- } \\
\text { turn relative to all other funds in the same market } \\
\text { segment (based on the Morningstar style boxes) in } \\
\text { a given month normalized to be between } 0 \text { and } 1 \text {. }\end{array}$ & CRSP, AE \\
\hline Performance rank ${ }^{2}$ & Squared value of performance rank. & CRSP, AE \\
\hline Three-months returns & A fund's net return over the past three months. & CRSP, AE \\
\hline One-year returns & A fund's net return over the past 12 months. & CRSP, AE \\
\hline Five-year returns & A fund's net return over the past 60 months. & CRSP, AE \\
\hline Fund risk & $\begin{array}{l}\text { Time series standard deviation of a fund's returns } \\
\text { using the rolling twelve-months window of past } \\
\text { returns. }\end{array}$ & CRSP, AE \\
\hline Fund age & $\begin{array}{l}\text { Logarithm of a fund's age in full years from the } \\
\text { date the fund was first offered, as defined in CRSP. }\end{array}$ & CRSP, AE \\
\hline Fund size & $\begin{array}{l}\text { Logarithm of a fund's total net assets in million } \\
\text { USD. }\end{array}$ & CRSP, AE \\
\hline Turnover ratio & A fund's turnover ratio. & CRSP \\
\hline Expense ratio & A fund's expense ratio in $\%$. & CRSP \\
\hline Marketing expenses & $\begin{array}{l}\text { Share of a fund's marketing expenses in its total } \\
\text { expenses. }\end{array}$ & $\mathrm{SEC}, \mathrm{AE}, \mathrm{MC}$ \\
\hline Family flow & $\begin{array}{l}\text { Average of fund flows over all funds belonging to } \\
\text { the same fund family as a given fund in a given } \\
\text { month, net of flows in a fund itself. }\end{array}$ & CRSP, AE \\
\hline No load fund & $\begin{array}{l}\text { Dummy variable equal to } 1 \text { if a fund does not } \\
\text { charge a front-end load fee in a given month and } \\
0 \text { otherwise. }\end{array}$ & CRSP \\
\hline Retail fund & $\begin{array}{l}\text { Dummy variable equal to } 1 \text { if a fund is a retail } \\
\text { fund in a given month and } 0 \text { otherwise. }\end{array}$ & CRSP \\
\hline Institutional fund & $\begin{array}{l}\text { Dummy variable equal to } 1 \text { if a fund is an institu- } \\
\text { tional fund in a given month and } 0 \text { otherwise. }\end{array}$ & CRSP \\
\hline Defense holdings & $\begin{array}{l}\text { Share of defense stocks in total fund's portfolio in } \\
\text { a given month. }\end{array}$ & $\mathrm{TR}$ \\
\hline Lagged fund flow & One month lagged flows of a given fund. & CRSP, AE \\
\hline
\end{tabular}

\section{Continued on next page...}


Table A.1 - continued from previous page.

\begin{tabular}{|c|c|c|}
\hline Variables & Description & Source \\
\hline Investment media & $\begin{array}{l}\text { Dummy variable equal to } 1 \text { for funds that disclose } \\
\text { information on manager's prior military experi- } \\
\text { ence through investment media sources and } 0 \text { oth- } \\
\text { erwise. }\end{array}$ & $\mathrm{MC}, \mathrm{MS}, \mathrm{BL}$ \\
\hline Personal disclosures & $\begin{array}{l}\text { Dummy variable equal to } 1 \text { if information on man- } \\
\text { ager's prior military experience is not available in } \\
\text { investment outlets, but on fund company websites } \\
\text { or professional networks and } 0 \text { otherwise. }\end{array}$ & $\mathrm{MC}, \mathrm{FW}, \mathrm{LI}$ \\
\hline Other sources & $\begin{array}{l}\text { Dummy variable equal to } 1 \text { if military background } \\
\text { information is only disclosed via major or regional } \\
\text { newspapers or other alternative media outlets and } \\
0 \text { otherwise. }\end{array}$ & $\mathrm{MC}, \mathrm{NP}$ \\
\hline Post-mortem placebo & $\begin{array}{l}\text { Dummy variable equal to } 1 \text { if military background } \\
\text { information is only disclosed in obituary notices } \\
\text { after manager passing, but not prior to that. } \\
\text { Based on additionally collected data. }\end{array}$ & MC, LEG \\
\hline \multicolumn{3}{|c|}{ Panel D: Manager-Specific and Other Variables } \\
\hline Age & $\begin{array}{l}\text { Biological age of a manager in years in a given } \\
\text { month. }\end{array}$ & $\begin{array}{l}\text { MS, BL, INT, } \\
\text { FW, NP, MC }\end{array}$ \\
\hline $\begin{array}{l}\text { Married (Marital sta- } \\
\text { tus) }\end{array}$ & $\begin{array}{l}\text { Dummy variable equal to } 1 \text { if a fund manager is } \\
\text { married in a given month and } 0 \text { otherwise. }\end{array}$ & $\begin{array}{l}\text { MS, INT, FW, } \\
\text { NP, MC }\end{array}$ \\
\hline Fund tenure & $\begin{array}{l}\text { Tenure of a manager in years in a given month, } \\
\text { computed as difference between a current date and } \\
\text { the date when the manager has started managing } \\
\text { the fund. }\end{array}$ & MS, FINRA, AE \\
\hline Industry tenure & $\begin{array}{l}\text { Tenure of a manager in years in a given month, } \\
\text { computed as difference between a current date and } \\
\text { the date when the manager joined the fund man- } \\
\text { agement industry. }\end{array}$ & MS, FINRA, AE \\
\hline Bachelors only & $\begin{array}{l}\text { Dummy variable equal to } 1 \text { if a manager has a } \\
\text { bachelor's degree as the highest degree earned and } \\
0 \text { otherwise. }\end{array}$ & $\begin{array}{l}\text { MS, BL, LI, MQ, } \\
\text { MC }\end{array}$ \\
\hline MBA and above & $\begin{array}{l}\text { Dummy variable equal to } 1 \text { if a manager has a } \\
\text { MBA/PhD/JD/MD degree as the highest degree } \\
\text { earned and } 0 \text { otherwise. }\end{array}$ & $\begin{array}{l}\text { MS, BL, LI, MQ, } \\
\text { MC }\end{array}$ \\
\hline Ivy league & $\begin{array}{l}\text { Dummy variable equal to } 1 \text { if a manager has any } \\
\text { degree from an Ivy league school and } 0 \text { otherwise. }\end{array}$ & $\begin{array}{l}\text { MS, BL, LI, MQ, } \\
\text { MC }\end{array}$ \\
\hline
\end{tabular}

Continued on next page... 
Table A.1 - continued from previous page.

\begin{tabular}{|c|c|c|}
\hline Variables & Description & Source \\
\hline Foreign name & $\begin{array}{l}\text { Dummy variable equal to } 1 \text { if a manager's name } \\
\text { is perceived as non-English sounding (but rather } \\
\text { as Muslim, Hispanic, African, Asian, etc.), and } 0 \\
\text { otherwise. Estimations based on Ye et al. (2017) } \\
\text { machine-learning algorithm. }\end{array}$ & $\mathrm{AE}$ \\
\hline $\begin{array}{l}\text { Non-financial industry } \\
\text { experience }\end{array}$ & $\begin{array}{l}\text { Dummy variable equal to } 1 \text { if a manager has prior } \\
\text { non-financial industry experience and } 0 \text { otherwise. }\end{array}$ & MS, BL, LI, MC \\
\hline Media coverage & $\begin{array}{l}\text { Number of articles about a manager in the whole } \\
\text { LexisNexis "U.S. newspapers" universe in a given } \\
\text { month. }\end{array}$ & $\mathrm{LN}, \mathrm{MC}$ \\
\hline Father manager & $\begin{array}{l}\text { Dummy variable equal to } 1 \text { if a manager's father } \\
\text { has worked in the asset management industry and } \\
0 \text { otherwise. }\end{array}$ & $\begin{array}{l}\text { MS, MQ, ANC, } \\
\text { LEG, NP, MC }\end{array}$ \\
\hline $\begin{array}{l}\text { Confidence in the mili- } \\
\text { tary index }\end{array}$ & $\begin{array}{l}\text { Normalized confidence in the military index in a } \\
\text { given year, computed as ratio of "great deal con- } \\
\text { fidence" to "very little/none confidence" respon- } \\
\text { dents in a given year. Survey data (every year) is } \\
\text { based on a random sample of more } 1,000 \text { adults, } \\
\text { aged } 18 \text { and older, from all } 50 \text { U.S. states. }\end{array}$ & Gallup, AE \\
\hline $\begin{array}{l}\text { Satisfaction in the mili- } \\
\text { tary }\end{array}$ & $\begin{array}{l}\text { Normalized satisfaction in the nation's military } \\
\text { strength and preparedness index in a given year. }\end{array}$ & Gallup, AE \\
\hline Firearm checks (NICS) & $\begin{array}{l}\text { The percentage change in the number of back- } \\
\text { ground checks on purchases of firearms conducted } \\
\text { through the National Instant Criminal Back- } \\
\text { ground Check System. }\end{array}$ & FBI, AE \\
\hline Tailhook scandal & $\begin{array}{l}\text { Dummy variable equal to } 1 \text { for three months fol- } \\
\text { lowing September } 1991 \text { and } 0 \text { otherwise. }\end{array}$ & $\mathrm{MC}$ \\
\hline $\begin{array}{l}\text { Naval Academy's cheat- } \\
\text { ing scandal }\end{array}$ & $\begin{array}{l}\text { Dummy variable equal to } 1 \text { for three months fol- } \\
\text { lowing January } 1994 \text { and } 0 \text { otherwise. }\end{array}$ & $\mathrm{MC}$ \\
\hline Abu Ghraib scandal & $\begin{array}{l}\text { Dummy variable equal to } 1 \text { for three months fol- } \\
\text { lowing April } 2004 \text { (the outburst of the scandal) } \\
\text { and } 0 \text { otherwise. }\end{array}$ & $\mathrm{MC}$ \\
\hline $\begin{array}{l}\text { Lackland AFB sex scan- } \\
\text { dal }\end{array}$ & $\begin{array}{l}\text { Dummy variable equal to } 1 \text { for three months fol- } \\
\text { lowing February } 2013 \text { and } 0 \text { otherwise. }\end{array}$ & $\mathrm{MC}$ \\
\hline Operation Red Dawn & $\begin{array}{l}\text { Dummy variable equal to } 1 \text { for three months fol- } \\
\text { lowing December } 2003 \text { (capture of Saddam Hus- } \\
\text { sein) and } 0 \text { otherwise. }\end{array}$ & $\mathrm{MC}$ \\
\hline $\begin{array}{l}\text { Operation } \\
\text { Spear }\end{array}$ & $\begin{array}{l}\text { Dummy variable equal to } 1 \text { for three months fol- } \\
\text { lowing May } 2011 \text { (death of Osama bin Laden) and } \\
0 \text { otherwise. }\end{array}$ & $\mathrm{MC}$ \\
\hline
\end{tabular}




\section{Appendix B. Military Background Information}

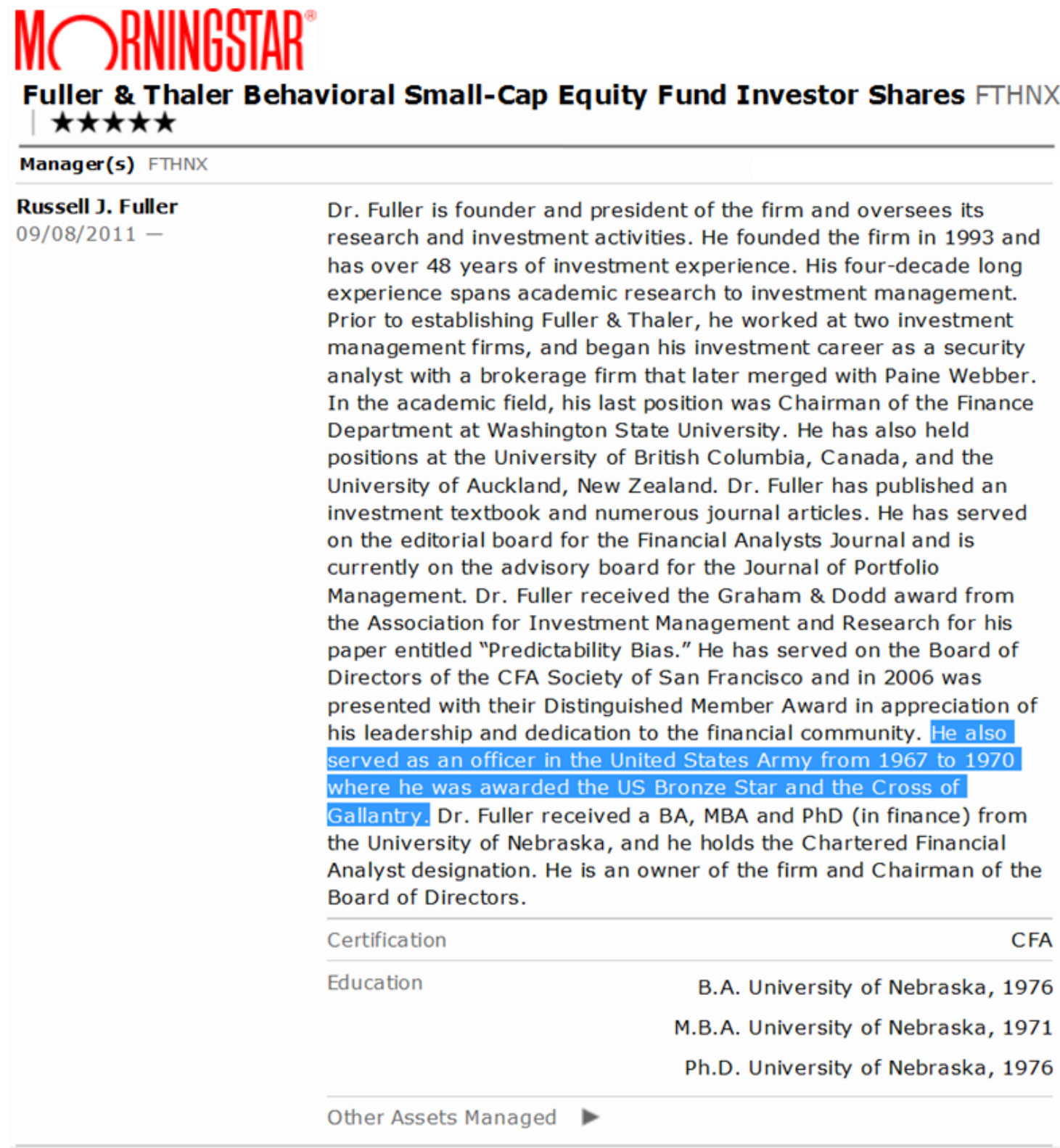

Fig. B.1. Morningstar sample profile of a fund manager with military background. This figure shows an exemplary manager profile retrieved from Morningstar Direct. The information regarding the manager's military background is highlighted in blue. 


\section{Bloomberg}

Executive Profile

\section{Anthony Eugene Sutton}

Portfolio Manager \& Analyst, Redwood Investments, LLC

Age Total Calculated Compensation This person is connected to $\mathbf{0}$ Board Member in $\mathbf{0}$ organization $55 \quad--$ across 3 different industries.

Background

Mr. Anthony Eugene Sutton, also known as Tony, is a Portfolio Manager and Analyst since 2012 at Redwood Investments, LLC. Mr. Sutton joined the firm in 2010 and serves as Portfolio Manager for SMID growth and Analyst for the large cap core and large cap growth strategies. His primary research coverage includes biotechnology, medical equipment, software, and services. Prior to joining this, Mr. Sutton was a Managing Director and Portfolio Manager at Putnam Investment Management, LLC. He joined the firm in 2001. Prior to this, he was a Specialty Growth Analyst at Putnam Investment Management covering health care, biotechnology, defense, and technology. Mr. Sutton was an Associate Analyst at Fidelity Management and Research from 1989 to 1993 and Portfolio Manager at Cabot Money Management from 1995 to 1998. He also served as the Chief Investment Officer at McDonald-Sutton Asset Management, LLC from 1998 to 2001. Mr. Sutton is a combat-decorated former US Marine, specializing in intelligence with extended tours served in the Middle East and Central America from 1982 to 1988. He began his investment career at Fidelity Investments and following graduate school, he managed growth portfolios for private clients. Mr. Sutton received M.B.A from MIT Sloan School of Management in 1993 and B.A. from Monmouth University in 1989.

Fig. B.2. Bloomberg sample profile of a fund manager with military background. This figure shows an exemplary manager profile retrieved from Bloomberg Executive Profiles. The information regarding the manager's military background is highlighted in blue. 


\section{Princeton Global}

\section{Asset Management LLC}

\section{Investment Professionals}

RONALD K. STRIBLEY, Managing Director, has implemented an investment philosophy focused on the "Value Style" for over 30 years. During this period he developed and refined a systematic and disciplined investment process that seeks to find equities which have low Price to Earnings Ratios with tangible evidence of improving corporate fundamentals. He is the founder of Stribley Capital Management. Ron was a partner in The Ayco Company L.P., a wholly owned subsidiary of Goldman Sachs, where he created, implemented, and managed a Value Style Portfolio. Prior to joining Ayco, Ron was First Vice President for The Glenmede Trust Company, where he managed in excess of $\$ 2.5$ Billion including the large capitalization US equity Pew Charitable Trust portfolio. Ron is a CFA ${ }^{\otimes}$ Charterholder since 1975 and has passed the NASD Series 7 and 66 examinations. He received his BSBA degrees from Babson College and then served a tour of duty in Viet Nam with the 11th Armored Calvary Regiment and was awarded the Bronze Star. Following his honorable discharge as a 1st Lieutenant, he completed his Masters at Babson College.

Fig. B.3. A fund firm's sample profile of a fund manager with military background. This figure shows an exemplary manager profile retrieved from a fund firm's advertising materials. The information regarding the manager's military background is highlighted in blue. 


\section{References}

Agarwal, V., Gay, G. D., Ling, L., 2014. Window dressing in mutual funds. The Review of Financial Studies 27, 3133-3170.

Agarwal, V., Lu, Y., Ray, S., 2018. Are hedge fund managers' charitable donations strategic? Available at SSRN 3290082.

Agarwal, V., Ma, L., Mullally, K., 2015. Managerial multitasking in the mutual fund industry. CFR Working Papers 13-10 [rev.], University of Cologne, Centre for Financial Research (CFR).

Barber, B. M., Odean, T., Zheng, L., 2005. Out of sight, out of mind: The effects of expenses on mutual fund flows. The Journal of Business 78, 2095-2120.

Benmelech, E., Frydman, C., 2015. Military ceos. Journal of Financial Economics 117, 43-59.

Bergstresser, D., Chalmers, J. M. R., Tufano, P., 2009. Assessing the costs and benefits of brokers in the mutual fund industry. The Review of Financial Studies 22, 4129-4156.

Berk, J. B., Green, R. C., 2004. Mutual fund flows and performance in rational markets. Journal of Political Economy 112, 1269-1295.

Blader, S. L., Tyler, T. R., 2009. Testing and extending the group engagement model: Linkages between social identity, procedural justice, economic outcomes, and extrarole behavior. Journal of Applied Psychology 94, 445.

Blanco, L., Ruiz, I., 2013. The impact of crime and insecurity on trust in democracy and institutions. American Economic Review 103, 284-88.

Bound, J., Turner, S., 2002. Going to war and going to college: Did world war ii and the gi bill increase educational attainment for returning veterans? Journal of Labor Economics $20,784-815$.

Cao, L., Cullen, F. T., Link, B. G., 1997. The social determinants of gun ownership: Selfprotection in an urban environment. Criminology 35, 629-658.

Carhart, M. M., 1997. On persistence in mutual fund performance. The Journal of Finance $52,57-82$.

Carlson, J. D., 2012. 'i don't dial 911' american gun politics and the problem of policing. British Journal of Criminology 52, 1113-1132. 
Chevalier, J., Ellison, G., 1999. Career concerns of mutual fund managers. The Quarterly Journal of Economics 114, 389-432.

Chuprinin, O., Sosyura, D., 2018. Family descent as a signal of managerial quality: Evidence from mutual funds. The Review of Financial Studies 31, 3756-3820.

Cialdini, R. B., Goldstein, N. J., 2004. Social influence: Compliance and conformity. Annual Review of Psychology 55, 591-621.

Cici, G., Gehde-Trapp, M., Göricke, M.-A., Kempf, A., 2018. The investment value of fund managers' experience outside the financial sector. The Review of Financial Studies 31, $3821-3853$.

Cohen, L., Frazzini, A., Malloy, C., 2008. The small world of investing: Board connections and mutual fund returns. Journal of Political Economy 116, 951-979.

Cooper, M. J., Dimitrov, O., Rau, P. R., 2001. A rose. com by any other name. The Journal of Finance 56, 2371-2388.

Cooper, M. J., Gulen, H., Rau, P. R., 2005. Changing names with style: Mutual fund name changes and their effects on fund flows. The Journal of Finance 60, 2825-2858.

Dangl, T., Wu, Y., Zechner, J., 2006. Market discipline and internal governance in the mutual fund industry. The Review of Financial Studies 21, 2307-2343.

De Tray, D., 1982. Veteran status as a screening device. American Economic Review 72, $133-42$.

Del Guercio, D., Tkac, P. A., 2008. Star power: The effect of monrningstar ratings on mutual fund flow. Journal of Financial and Quantitative Analysis 43, 907-936.

Diener, E., Kerber, K. W., 1979. Personality characteristics of american gun-owners. The Journal of Social Psychology 107, 227-238.

Duffy, T., 2006. Military Experience \& CEOs: Is There a Link? Korn/Ferry International.

Egan, M., Matvos, G., Seru, A., 2019. The market for financial adviser misconduct. Journal of Political Economy 127, 233-295.

Fama, E. F., French, K. R., 1993. Common risk factors in the returns on stocks and bonds. Journal of financial economics $33,3-56$. 
Fama, E. F., French, K. R., 2010. Luck versus skill in the cross-section of mutual fund returns. The Journal of Finance 65, 1915-1947.

Frazzini, A., Lamont, O., 2008. Dumb money: Mutual fund flows and the cross-section of stock returns. Journal of Financial Economics 88, 299-322.

Gennaioli, N., Shleifer, A., Vishny, R., 2015. Money doctors. The Journal of Finance 70, 91-114.

Glazer, J., Rubinstein, A., 2004. On optimal rules of persuasion. Econometrica 72, 17151736.

Guiso, L., Sapienza, P., Zingales, L., 2004. The role of social capital in financial development. American Economic Review 94, 526-556.

Hirshleifer, D., 2001. Investor psychology and asset pricing. The Journal of Finance 56, $1533-1597$.

Hoechle, D., Ruenzi, S., Schaub, N., Schmid, M., 2018. Financial advice and bank profits. The Review of Financial Studies 31, 4447-4492.

Hooghe, M., Oser, J., 2017. Partisan strength, political trust and generalized trust in the united states: An analysis of the general social survey, 1972-2014. Social Science Research $68,132-146$.

Hortaçsu, A., Syverson, C., 2004. Product differentiation, search costs, and competition in the mutual fund industry: A case study of s\&p 500 index funds. The Quarterly Journal of Economics 119, 403-456.

Huddy, L., Khatib, N., 2007. American patriotism, national identity, and political involvement. American Journal of Political Science 51, 63-77.

Jackson, J. J., Thoemmes, F., Jonkmann, K., Lüdtke, O., Trautwein, U., 2012. Military training and personality trait development: Does the military make the man, or does the man make the military? Psychological Science 23, 270-277.

Jain, P. C., Wu, J. S., 2000. Truth in mutual fund advertising: Evidence on future performance and fund flows. The Journal of Finance 55, 937-958.

Jensen, M. C., 1968. The performance of mutual funds in the period 1945-1964. The Journal of Finance 23, 389-416. 
Kaniel, R., Starks, L. T., Vasudevan, V., 2007. Headlines and bottom lines: attention and learning effects from media coverage of mutual funds. Available at SSRN 687103.

Khorana, A., 1996. Top management turnover an empirical investigation of mutual fund managers. Journal of Financial Economics 40, 403-427.

Knack, S., Keefer, P., 1997. Does social capital have an economic payoff? a cross-country investigation. The Quarterly Journal of Economics 112, 1251-1288.

Koch-Bayram, I. F., Wernicke, G., 2018. Drilled to obey? ex-military ceos and financial misconduct. Strategic Management Journal 39, 2943-2964.

Kostovetsky, L., 2015. Whom Do You Trust?: Investor-Advisor Relationships and Mutual Fund Flows. The Review of Financial Studies 29, 898-936.

Kronlund, M., Pool, V. K., Sialm, C., Stefanescu, I., 2019. Out of sight no more? the effect of fee disclosures on $401(\mathrm{k})$ investment allocations. Indiana university kelley school of business research paper series.

Kumar, A., Niessen-Ruenzi, A., Spalt, O. G., 2015. What's in a name? mutual fund flows when managers have foreign-sounding names. The Review of Financial Studies 28, 22812321.

Lakonishok, J., Shleifer, A., Thaler, R. H., Vishny, R. W., 1991. Window dressing by pension fund managers. American Economic Review Papers and Proceedings May.

MacLean, A., Elder Jr, G. H., 2007. Military service in the life course. Annual Review of Sociology 33, 175-196.

Malmendier, U., Tate, G., Yan, J., 2011. Overconfidence and early-life experiences: the effect of managerial traits on corporate financial policies. The Journal of Finance 66, 1687-1733.

Mullainathan, S., Schwartzstein, J., Shleifer, A., 2008. Coarse thinking and persuasion. The Quarterly Journal of Economics 123, 577-619.

Niessen-Ruenzi, A., Ruenzi, S., 2018. Sex matters: Gender bias in the mutual fund industry. Management Science .

Pástor, L., Stambaugh, R. F., Taylor, L. A., 2015. Scale and skill in active management. Journal of Financial Economics 116, 23-45. 
Patel, S., Sarkissian, S., 2013. Deception and managerial structure: A joint study of portfolio pumping and window dressing practices. Unpublished working paper. University of Western Ontario .

Patel, S., Sarkissian, S., 2017. To group or not to group? evidence from mutual fund databases. Journal of Financial and Quantitative Analysis 52, 1989-2021.

Petrocik, J. R., 2009. Measuring party support: Leaners are not independents. Electoral Studies 28, 562-572.

Pope, D. G., Sydnor, J. R., 2011. What's in a picture? evidence of discrimination from prosper.com. Journal of Human Resources 46, 53-92.

Rahn, W. M., Transue, J. E., 1998. Social trust and value change: The decline of social capital in american youth, 1976-1995. Political Psychology 19, 545-565.

Roussanov, N., Savor, P., 2014. Marriage and managers' attitudes to risk. Management Science 60, 2496-2508.

Sampson, R. J., Laub, J. H., 1996. Socioeconomic achievement in the life course of disadvantaged men: Military service as a turning point, circa 1940-1965. American Sociological Review pp. 347-367.

Sapp, T., Tiwari, A., 2004. Does stock return momentum explain the "smart money" effect? Journal of Finance 59, 2605-2622.

Solomon, D. H., Soltes, E., Sosyura, D., 2014. Winners in the spotlight: Media coverage of fund holdings as a driver of flows. Journal of Financial Economics 113, 53-72.

Spiegel, M., Zhang, H., 2013. Mutual fund risk and market share-adjusted fund flows. Journal of Financial Economics 108, 506-528.

Teigen, J. M., 2013. Military experience in elections and perceptions of issue competence: An experimental study with television ads. Armed Forces Society 39, 415-433.

Ye, J., Han, S., Hu, Y., Coskun, B., Liu, M., Qin, H., Skiena, S., 2017. Nationality classification using name embeddings. In: Proceedings of the 2017 ACM on Conference on Information and Knowledge Management, ACM, New York, NY, USA, CIKM '17, pp. 1897-1906. 


\section{Table 1. Fund and Manager Characteristics}

This table reports fund and manager characteristics for our sample of funds managed by individuals with prior military experience and for the peer managers who do not have such experience. Both groups of funds include fund managers who single-managed U.S. domestic equity funds at some point between 1991 and 2017. The differences between the group means and the corresponding t-statistics, clustered by fund for fund attributes and clustered by manager for manager attributes, are reported in columns (3) and (4), respectively. Panel A reports fund characteristics. Fund flows are the net percentage flows of the fund in a given month (annualized), as specified in the equation (1). Other fund characteristics include: Raw returns (annualized); Performance rank of the fund in a given month relative to all other funds in the same market segment; Fund risk (time series standard deviation of the fund returns using the rolling past twelve month return observations); Fund age measured as the natural logarithm of fund age in years in a given month; Fund size as natural logarithm of the fund's size in million USD; Turnover ratio; Expense ratio; marketing expenses as the share of marketing expenses (NSAR-B filings) in total expenses; Morningstar rating; Family flows as the monthly growth rate of fund's family; Defense holdings as the share of defense stocks in total fund's portfolio in a given month; and indicator variables for No load, Retail, and Institutional funds. Panel B reports specific manager characteristics, including biological age, fund and industry tenure, and share of managers with foreign name. The panel also reports the fractions of managers by their top degree and Ivy league school attainment. Manager's media coverage is the number of times a fund manager is mentioned in a given month in all U.S. newspapers.

\begin{tabular}{lcccc}
\hline Panel A: Fund Characteristics & & & \\
\hline Variable & Military managers & Other managers & Difference & t-statistic \\
& $(1)$ & $(2)$ & $(3)$ & $(4)$ \\
\cline { 2 - 5 } Fund flows & 0.224 & 0.118 & 0.106 & 5.06 \\
Returns (raw) & 0.096 & 0.091 & 0.005 & 0.79 \\
Performance rank & 0.556 & 0.552 & 0.004 & 1.13 \\
Performance rank & 0.394 & 0.390 & 0.004 & 0.95 \\
Fund risk & 0.045 & 0.047 & -0.001 & -1.27 \\
Fund age & 1.882 & 2.056 & -0.174 & -1.38 \\
Fund size & 4.887 & 5.078 & -0.190 & -0.94 \\
Turnover & 0.863 & 0.827 & 0.036 & 0.31 \\
Morningstar rating & 3.175 & 3.098 & 0.077 & 0.62 \\
Expense ratio & 0.012 & 0.012 & -0.001 & -1.47 \\
Marketing expenses & 0.341 & 0.332 & 0.009 & 0.35 \\
Family flows & 0.010 & 0.006 & 0.007 & 1.65 \\
No load fund & 0.219 & 0.197 & 0.022 & 0.49 \\
Retail fund & 0.719 & 0.873 & -0.154 & -0.88 \\
Institutional fund & 0.489 & 0.476 & 0.012 & 0.27 \\
Defense holdings & 1.379 & 1.485 & -0.106 & -0.78 \\
\hline Panel B: Manager Characteristics & & & \\
Age & 53.003 & 46.773 & 6.230 & 3.96 \\
Married & 0.851 & 0.856 & -0.005 & -1.17 \\
Fund tenure & 8.038 & 6.513 & 1.524 & 1.19 \\
Industry tenure & 11.144 & 9.155 & 1.989 & 1.80 \\
Bachelors only & 0.237 & 0.288 & -0.051 & -0.80 \\
MBA top & 0.682 & 0.587 & 0.095 & 1.22 \\
PhD/JD/MD top & 0.054 & 0.059 & -0.004 & -0.11 \\
Ivy league bachelors & 0.215 & 0.149 & 0.066 & 0.87 \\
Ivy league MBA & 0.230 & 0.227 & 0.003 & 0.04 \\
Ivy league & 0.406 & 0.305 & 0.101 & 1.04 \\
Foreign name & 0.229 & 0.298 & -0.069 & -0.87 \\
Media coverage & 2.405 & 2.192 & 0.214 & 0.56 \\
\hline \hline & & & \\
\hline
\end{tabular}


Table 2. Military Background of Mutual Fund Managers and Fund Flows

This table relates manager's military background to fund flows. The dependent variable is monthly net percentage fund flows. The main independent variable is the military dummy that equals one if a fund is single-managed by an individual with military background in a given month and zero if the active manager does not have a military background. The set of control variables is comprised of variables described in Table 1 and in Appendix A. All control variables, except family flows, are lagged by one month. Segment is defined by the Morningstar fund style indicator. Specification (1) reports results of percentage fund flow regression without fixed effects. Regression specifications (2) to (6) include period, segment, family, fund, and/or interaction fixed effects. Period FE stands for month-year fixed effects. Standard errors are double-clustered by fund and month-year. The corresponding t-statistics are reported in parentheses.

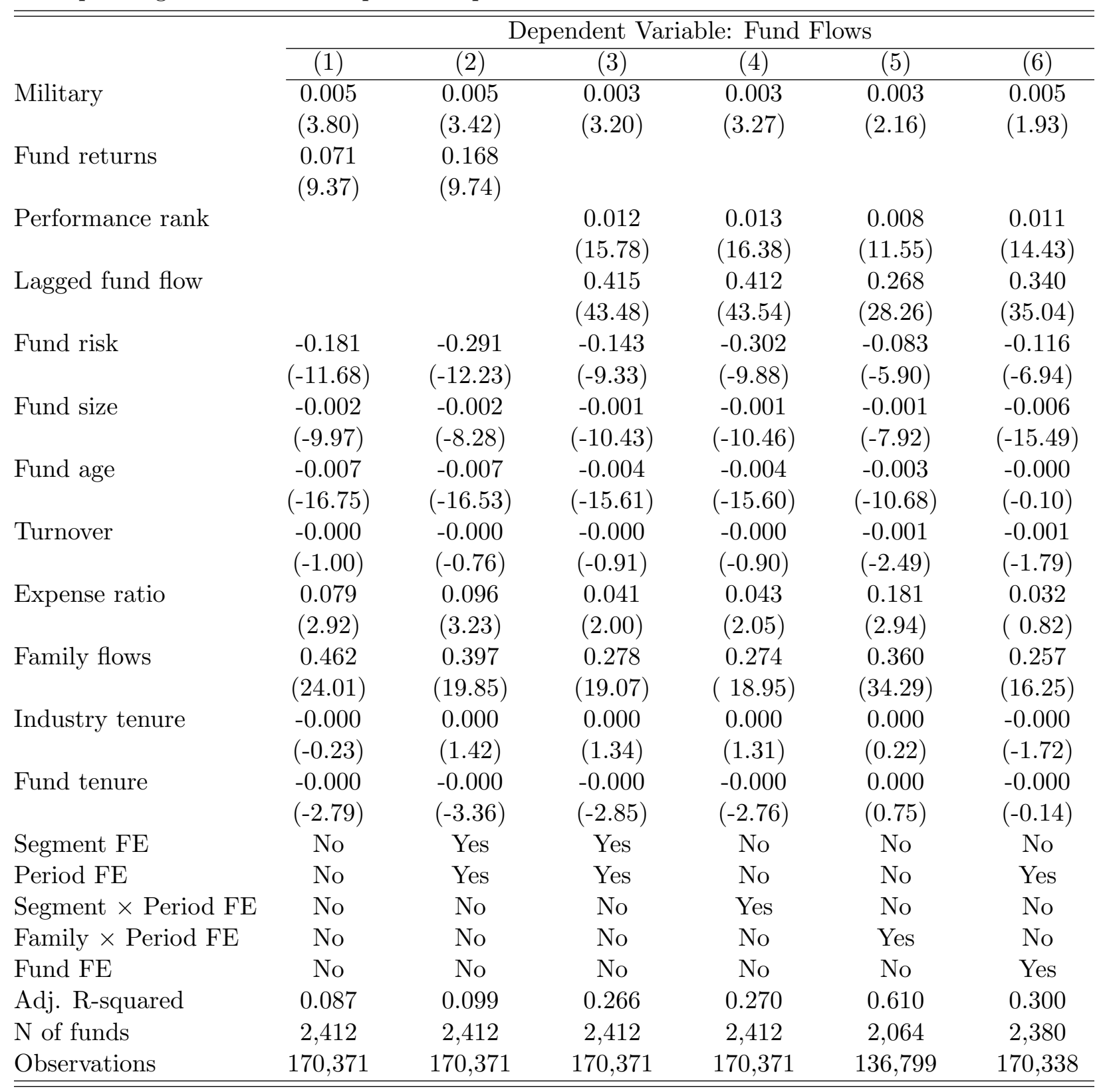




\section{Table 3. Alternative Explanations and Robustness of the Results}

This table reports results of robustness tests. Specifically, this table shows the estimates of net percentage fund flows regressed on the military dummy, but, depending on the robustness test, flow regressions include additional control variables or are estimated with an adjusted sample of funds. Additional control variables for managerial attributes include manager's gender, biological age, marital status, education, prior experience, foreignness of a name, father background, and media coverage. Additional control variables for fund attributes include long-term performance; retail, institutional and no load fund indicators; the share of defense stocks in the fund portfolio; and the share of fund marketing expenses in a given month. All of the variables are described in Appendix A. The setup also includes the standard set of control variables and is otherwise identical to the specification (3) of Table 2. Standard errors are double-clustered by fund and month-year.

\begin{tabular}{|c|c|c|c|c|c|}
\hline \multicolumn{2}{|c|}{$\overline{\text { Alternative explanations }}$} & \multicolumn{4}{|c|}{ Dependent Variable: Fund Flows } \\
\hline & & Coefficient & t-statistic & No of funds & Observations \\
\hline (1) & Return 3-months control & 0.002 & 2.97 & 2,403 & 168,901 \\
\hline$(2)$ & Return 1-year control & 0.002 & 2.20 & 2,297 & 155,467 \\
\hline$(3)$ & Return 5-year control & 0.002 & 2.18 & 1,612 & 96,689 \\
\hline (4) & Defense holdings share control & 0.002 & 2.22 & 2,167 & 76,967 \\
\hline \multirow[t]{4}{*}{ (5) } & \multicolumn{5}{|c|}{ Coefficient estimates (military) when controlling for demographics } \\
\hline & Gender & 0.003 & 3.16 & 2,412 & 170,371 \\
\hline & Gender and age & 0.003 & 3.93 & 2,399 & 169,123 \\
\hline & Gender, age and marital status & 0.004 & 4.05 & 2,242 & 153,147 \\
\hline \multirow[t]{3}{*}{ (6) } & Coefficient estimates (military) whe & controlling & r degree & & \\
\hline & Bachelors only & 0.003 & 3.13 & 2,406 & 169,843 \\
\hline & MBA and above & 0.003 & 3.25 & & \\
\hline \multirow[t]{3}{*}{$(7)$} & Controlling for the level of recogniti & n of educati & & & \\
\hline & Military & 0.003 & 3.11 & 2,402 & 169,556 \\
\hline & Ivy league & 0.001 & 3.45 & & \\
\hline \multirow[t]{3}{*}{$(8)$} & Non-Financial Industry experience & & & & \\
\hline & Military & 0.003 & 3.17 & 2,406 & 169,887 \\
\hline & Non-financial industry experience & 0.000 & 0.21 & & \\
\hline \multirow[t]{3}{*}{$(9)$} & Foreign name & & & & \\
\hline & Military & 0.003 & 3.32 & 2,412 & 170,371 \\
\hline & Foreign name & -0.001 & -2.79 & & \\
\hline \multirow[t]{3}{*}{$(10)$} & Manager's family background & & & & \\
\hline & Military & 0.004 & 2.98 & 1,014 & 56,656 \\
\hline & Father fund manager & 0.002 & 1.41 & & \\
\hline \multirow[t]{3}{*}{$(11)$} & Marketing expenses & & & & \\
\hline & Military & 0.004 & 3.18 & 1,665 & 101,465 \\
\hline & Marketing expenses & 0.000 & 3.98 & & \\
\hline \multirow[t]{4}{*}{$(12)$} & Coefficient estimates (military) by $\mathrm{c}$ & stribution $\mathrm{cl}$ & nnels & & \\
\hline & Retail fund & 0.003 & 3.24 & 2,404 & 170,264 \\
\hline & Institutional fund & 0.003 & 3.09 & 2,404 & 170,264 \\
\hline & No Load Fund & 0.003 & 3.21 & 2,412 & 170,371 \\
\hline \multirow[t]{3}{*}{$(13)$} & Manager's media coverage control & & & & \\
\hline & Military & 0.002 & 2.38 & 1,391 & 134,293 \\
\hline & Media coverage & 0.000 & 0.14 & & \\
\hline$(14)$ & Excluding index funds & 0.005 & 2.83 & 2,154 & 153,447 \\
\hline$(15)$ & Placebo: Subsample of index funds & 0.002 & 0.45 & 258 & 16,899 \\
\hline
\end{tabular}


Table 4. Fund Flows and the Degree of Military Involvement

This table relates percentage fund flows to the manager's degree of involvement in the military. Panel A presents results of a univariate sorting by the Conflict/Medal dummy and the Military training indicator variable. The Conflict/Medal dummy equals one if a fund is managed by an individual who served a tour of duty in a conflict zone and zero otherwise. The Military training dummy covers another extreme of military involvement and takes the value of one if a manager has never served in the military but has graduated from any of the U.S. military schools and academies or participated in any type of military training and zero otherwise. The Conflict/Medal indicator variable represents a subset of military managers, while the Military training dummy covers additionally collected data on managers who have only undergone military training. Panel $\mathrm{B}$ shows the estimates of net percentage fund flows regressed on the aforementioned variables and the interaction term with the military dummy. The setup of the regressions includes the standard set of control variables and is otherwise identical to the baseline specification (3) of Table 2. Standard errors are double-clustered by fund and month-year and t-statistics are reported in parentheses.

\begin{tabular}{lcccc}
\hline \hline Panel A: Univariate sorting & \multicolumn{4}{c}{ Fund Flows } \\
\cline { 2 - 5 } Conflict/Medal & Military managers & Other managers & Difference & t-statistic \\
Military training & 0.029 & 0.010 & 0.018 & 3.39 \\
\hline Panel B: Regression analysis & 0.010 & 0.010 & -0.001 & -0.16 \\
\cline { 2 - 5 } & \multicolumn{4}{c}{ Dependent Variable: Fund flows } \\
\cline { 2 - 5 } Military & 0.002 & $(2)$ & $(3)$ & $(4)$ \\
& $(2.70)$ & 0.002 & \\
Military $\times$ Conflict/Medal & 0.005 & $(2.55)$ & 0.007 & \\
& $(2.06)$ & 0.006 & $(2.70)$ & -0.001 \\
Military training & -0.003 & $(2.15)$ & \\
& $(-1.42)$ & & & Yes \\
Controls & Yes & Yes & Yes & Yes \\
Segment FE & Yes & Yes & Yes & Yes \\
Period FE & Yes & Yes & Yes & 0.266 \\
Adj. R-squared & 0.266 & 0.266 & 0.266 & 2,412 \\
N of funds & 2,412 & 2,412 & 2,412 & 170,371 \\
Observations & 170,371 & 170,371 & 170,371 & \\
\hline \hline
\end{tabular}




\section{Table 5. Information Distribution Channels and Fund Flows}

This table presents mean fund flows estimates from univariate sorting (Panel A) and coefficient estimates of net percentage fund flows from the regressions (Panel B) by four distinct distribution channels for military background information disclosure. The Investment media indicator variable equals one for funds that disclose information on manager's prior military experience through investment media sources, namely, Morningstar and Bloomberg, and zero otherwise. The Personal disclosures dummy is coded as one if this information is not available in investment outlets, but on fund company websites or professional networks, and zero otherwise. The Other sources variable takes the value of one if military background information is only disclosed via major or regional newspapers or other alternative media outlets, and zero otherwise. The Post-mortem placebo variable is one for cases in which military affiliation is disclosed in obituary notices after manager passing, but not prior to that. The first three variables represent subsets of military managers, while the Post-mortem placebo dummy covers additionally collected data. Panel B shows the estimates of net percentage fund flows regressed on the aforementioned variables. We use the same regression setup, including the standard set of control variables, as in the baseline specification (3) of Table 2. Standard errors are double-clustered by fund and month-year and t-statistics are reported in parentheses.

\begin{tabular}{|c|c|c|c|c|}
\hline \multirow[t]{2}{*}{ Panel A: Univariate sorting } & \multicolumn{4}{|c|}{ Fund flows } \\
\hline & Military managers & Other managers & Difference & t-statistic \\
\hline Investment media & 0.025 & 0.010 & 0.014 & 3.52 \\
\hline Personal disclosures & 0.028 & 0.010 & 0.018 & 6.27 \\
\hline Other sources & 0.011 & 0.010 & 0.000 & 0.11 \\
\hline Post-mortem placebo & 0.011 & 0.010 & 0.000 & 0.11 \\
\hline \multirow[t]{2}{*}{ Panel B: Regression analysis } & \multicolumn{4}{|c|}{ Dependent Variable: Fund flows } \\
\hline & $(1)$ & $(2)$ & $(3)$ & $(4)$ \\
\hline Investment media & $\begin{array}{l}0.006 \\
(3.14)\end{array}$ & & & \\
\hline Personal disclosures & & $\begin{array}{l}0.007 \\
(4.39)\end{array}$ & & \\
\hline Other sources & & & $\begin{array}{l}-0.001 \\
(-1.00)\end{array}$ & \\
\hline Post-mortem placebo & & & & $\begin{array}{l}-0.002 \\
(-1.39)\end{array}$ \\
\hline Controls & Yes & Yes & Yes & Yes \\
\hline Segment FE & Yes & Yes & Yes & Yes \\
\hline Period FE & Yes & Yes & Yes & Yes \\
\hline Adj. R-squared & 0.266 & 0.267 & 0.266 & 0.266 \\
\hline $\mathrm{N}$ of funds & 2,412 & 2,412 & 2,412 & 2,412 \\
\hline Observations & 170,371 & 170,371 & 170,371 & 170,371 \\
\hline
\end{tabular}


Table 6. Managers' Military Background and Fund Flows: Team-Managed Funds

This table reports the estimates of the regressions with monthly net percentage fund flows as the dependent variable and military team indicator as the explanatory variable. The military team dummy takes the value of one if a fund management team includes a manager with prior military background in a given month and equals zero if there are no military-experienced individuals in a team that manages a fund. The setup of the regressions includes the standard set of control variables (apart from manager-specific industry experience and fund tenure controls) and is otherwise identical to regression specifications of Table 2. Specifications (3) and (4) additionally include interaction terms with the share of military-experienced managers in a team and with three distinct information distribution channels (specified in Table 5), respectively. Standard errors are double-clustered by fund and month-year and t-statistics are reported in parentheses.

\begin{tabular}{|c|c|c|c|c|}
\hline & \multicolumn{4}{|c|}{ Dependent Variable: Fund Flows } \\
\hline & $(1)$ & $(2)$ & $(3)$ & $(4)$ \\
\hline \multirow[t]{2}{*}{ Military team } & 0.000 & 0.000 & -0.001 & 0.001 \\
\hline & $(0.11)$ & $(0.15)$ & $(-0.39)$ & $(0.25)$ \\
\hline \multirow[t]{2}{*}{ Military team share } & & & 0.003 & \\
\hline & & & $(0.43)$ & \\
\hline \multirow[t]{2}{*}{ Military team $\times$ Investment media } & & & & 0.001 \\
\hline & & & & $(0.35)$ \\
\hline \multirow{2}{*}{ Military team $\times$ Personal disclosures } & & & & -0.001 \\
\hline & & & & $(-0.55)$ \\
\hline \multirow[t]{2}{*}{ Military team $\times$ Other sources } & & & & -0.001 \\
\hline & & & & $(-0.20)$ \\
\hline \multirow[t]{2}{*}{ Lagged fund flow } & & 0.397 & 0.397 & 0.397 \\
\hline & & $(34.68)$ & $(34.68)$ & $(34.69)$ \\
\hline \multirow{2}{*}{ Performance rank } & 0.012 & 0.009 & 0.009 & 0.009 \\
\hline & $(12.91)$ & $(14.34)$ & $(14.33)$ & $(14.33)$ \\
\hline \multirow[t]{2}{*}{ Fund risk } & -0.284 & -0.159 & -0.159 & -0.159 \\
\hline & $(-10.63)$ & $(-8.73)$ & $(-8.73)$ & $(-8.74)$ \\
\hline \multirow[t]{2}{*}{ Fund size } & -0.000 & -0.000 & -0.000 & -0.000 \\
\hline & $(-1.03)$ & $(-0.17)$ & $(-0.16)$ & $(-0.11)$ \\
\hline \multirow[t]{2}{*}{ Fund age } & -0.008 & -0.004 & -0.004 & -0.004 \\
\hline & $(-18.63)$ & $(-17.53)$ & $(-17.52)$ & $(-17.49)$ \\
\hline \multirow{2}{*}{ Turnover ratio } & 0.001 & 0.001 & 0.001 & 0.001 \\
\hline & $(3.48)$ & $(3.29)$ & $(3.28)$ & $(2.28)$ \\
\hline \multirow[t]{2}{*}{ Expense ratio } & 0.048 & 0.022 & 0.022 & 0.019 \\
\hline & $(0.63)$ & $(0.47)$ & $(0.47)$ & $(0.40)$ \\
\hline \multirow[t]{2}{*}{ Family flow } & 0.294 & 0.211 & 0.211 & 0.211 \\
\hline & $(15.76)$ & $(14.66)$ & (14.67) & $(14.64)$ \\
\hline Segment FE & Yes & Yes & Yes & Yes \\
\hline Period FE & Yes & Yes & Yes & Yes \\
\hline Adj. R-squared & 0.080 & 0.232 & 0.232 & 0.232 \\
\hline $\mathrm{N}$ of funds & 2,019 & 2,019 & 2,019 & 2,019 \\
\hline Observations & 184,183 & 184,183 & 184,183 & 184,183 \\
\hline
\end{tabular}


Table 7. Fund Flows, Confidence in the Military, and Natural Experiments

This table relates fund flows to the nationwide confidence in the military and perceived insecurity. Panel A first reports estimates of the regressions of monthly net fund flows on military indicator for periods of high and low levels of confidence in the military, as classified based on the median level of the Gallup Poll's normalized confidence in the military index. Second, it shows the estimates of monthly net percentage fund flows regressed on the military dummy interacted with lagged Firearm checks (NICS) variable. Panel B reports results for the flow regressions augmented with interaction terms of the military variable with indicators for three months following the Tailhook scandal, the Naval Academy's cheating scandal, the Abu Ghraib scandal, the Lackland AFB sex scandal, the success of the Operation Red Dawn, and the success of the Operation Neptune Spear (see Appendix A). The setup of the regressions is otherwise identical to the baseline specification (3) of Table 2 . Standard errors are double-clustered by fund and month-year. t-statistics are in parentheses.

Panel A: Confidence index and NICS firearms checks

Dependent variable: Fund flows

\begin{tabular}{|c|c|c|c|c|c|}
\hline & \multicolumn{2}{|c|}{$\begin{array}{l}\text { Confidence in } \\
\text { Military index }\end{array}$} & \multicolumn{3}{|c|}{ NICS FBI Checks } \\
\hline & $\begin{array}{c}\text { Periods } \\
\text { (years) } \\
\text { of low } \\
\text { confidence }\end{array}$ & $\begin{array}{c}\text { Periods } \\
\text { (years) } \\
\text { of high } \\
\text { confidence }\end{array}$ & $\begin{array}{l}\text { NICS FBI } \\
\text { checks on } \\
\text { purchases } \\
(1998 / 12- \\
2017 / 12)\end{array}$ & $\begin{array}{l}\text { NICS FBI } \\
\text { checks on } \\
\text { purchases: } \\
\text { Periods of } \\
\text { pos. change }\end{array}$ & $\begin{array}{c}\text { NICS FBI } \\
\text { checks on } \\
\text { purchases: } \\
\text { Periods of } \\
\text { neg. change }\end{array}$ \\
\hline & $(1)$ & $(2)$ & $(3)$ & $(4)$ & $(5)$ \\
\hline Military & $\begin{array}{l}0.002 \\
(1.83)\end{array}$ & $\begin{array}{l}0.003 \\
(3.07)\end{array}$ & $\begin{array}{l}0.003 \\
(3.16)\end{array}$ & $\begin{array}{l}0.002 \\
(2.45)\end{array}$ & $\begin{array}{l}0.004 \\
(3.29)\end{array}$ \\
\hline $\begin{array}{l}\text { Military } \\
\times \text { NICS checks }\end{array}$ & & & $\begin{array}{l}-0.003 \\
(-2.70)\end{array}$ & & \\
\hline NICS checks & & & $\begin{array}{l}-0.006 \\
(-1.26)\end{array}$ & & \\
\hline Controls & Yes & Yes & Yes & Yes & Yes \\
\hline Segment FE & Yes & Yes & Yes & Yes & Yes \\
\hline Period FE & Yes & Yes & Yes & Yes & Yes \\
\hline Adj. R-squared & 0.272 & 0.262 & 0.246 & 0.243 & 0.248 \\
\hline $\mathrm{N}$ of funds & 2,104 & 2,059 & 2,267 & 2,252 & 2,206 \\
\hline Observations & 89,966 & 79,0746 & 136,025 & 81,432 & 53,826 \\
\hline
\end{tabular}

Panel B: Natural experiments

Dependent variable: Fund flows

\begin{tabular}{lcccccc}
\cline { 2 - 6 } & $\begin{array}{l}\text { Tailhook } \\
\text { scandal }\end{array}$ & $\begin{array}{c}\text { Naval Academy } \\
\text { scandal }\end{array}$ & $\begin{array}{c}\text { Abu } \\
\text { Ghraib }\end{array}$ & $\begin{array}{c}\text { Lackland } \\
\text { scandal }\end{array}$ & $\begin{array}{c}\text { Red } \\
\text { Dawn }\end{array}$ & $\begin{array}{c}\text { Neptune } \\
\text { Spear }\end{array}$ \\
\cline { 2 - 7 } Military & 0.003 & 0.003 & 0.003 & 0.003 & 0.003 & 0.003 \\
Military×event & $(3.08)$ & $(3.25)$ & $(3.26)$ & $(3.08)$ & $(3.08)$ & $(3.15)$ \\
& -0.004 & -0.006 & -0.006 & -0.010 & 0.009 & 0.014 \\
Controls & $(-4.51)$ & $(-2.52)$ & $(-2.31)$ & $(-2.40)$ & $(1.97)$ & $(2.58)$ \\
Segment FE & Yes & Yes & Yes & Yes & Yes & Yes \\
Period FE & Yes & Yes & Yes & Yes & Yes & Yes \\
Adj. R-squared & 0.266 & Yes & Yes & Yes & Yes & Yes \\
N of funds & 2,412 & 0.266 & 0.266 & 0.266 & 0.266 & 0.266 \\
Observations & 170,371 & 170,412 & 2,412 & 2,412 & 2,412 & 2,412 \\
\hline \hline
\end{tabular}




\section{Table 8. Fund Flows and Managerial Changes}

This table presents evidence on ordinary least squares estimates of the difference-in-differences design of equation (2). The dependent variable is monthly net fund inflows. The sample is restricted to funds with only one episode of change to single management over the period between 1991 and 2017. Treat is an indicator for funds that were ever managed by individuals with military background. Post indicator takes the value of one if a fund is solo-managed and zero if a fund is team-managed in a given month. Columns (3) to (5) present evidence on the timing of the effects of the managerial turnover on the fund flows outcome by presenting estimates of a modified version of equation (2). Pre1 and Pre2 are indicator variables for observations that fall during one and two months prior to management change, respectively. Post1 through Post3 indicate observations from one through three months after the managerial turnover occurred. Post0 is an indicator variable for observations that occur during the months of managerial change. Controls include: performance rank; fund size; fund risk; fund age; turnover ratio; expense ratio; and family flows. All control variables, except family flows, are lagged by one month and have been defined in Table 1 and in Appendix A. Segment is defined by the Morningstar fund style indicator. Period FE stands for month-year fixed effects. Standard errors are double-clustered by fund and month-year and t-statistics are reported in parentheses.

\begin{tabular}{|c|c|c|c|c|c|}
\hline \multirow[b]{3}{*}{ Treat $_{i}$} & \multicolumn{5}{|c|}{ Dependent Variable: Fund Flows } \\
\hline & $(1)$ & $(2)$ & $(3)$ & $(4)$ & $(5)$ \\
\hline & $\begin{array}{l}0.001 \\
(076)\end{array}$ & $\begin{array}{l}0.002 \\
(124)\end{array}$ & & & \\
\hline Treat $_{i} \times$ Post $_{t}$ & $\begin{array}{l}0.006 \\
(7.24)\end{array}$ & $\begin{array}{l}0.002 \\
(2.48)\end{array}$ & & & \\
\hline Treat $_{i} \times$ Pre 2 & & & $\begin{array}{l}0.004 \\
(0.34)\end{array}$ & & $\begin{array}{l}0.004 \\
(0.34)\end{array}$ \\
\hline Treat $_{i} \times$ Pre1 & & & $\begin{array}{l}0.005 \\
(0.33)\end{array}$ & & $\begin{array}{l}0.005 \\
(0.33)\end{array}$ \\
\hline Treat $_{i} \times$ Post0 & & & $\begin{array}{l}0.057 \\
(3.66)\end{array}$ & & $\begin{array}{l}0.057 \\
(3.66)\end{array}$ \\
\hline Treat $_{i} \times$ Post1 & & & & $\begin{array}{l}0.034 \\
(3.16)\end{array}$ & $\begin{array}{l}0.046 \\
(3.16)\end{array}$ \\
\hline Treat $_{i} \times$ Post 2 & & & & $\begin{array}{l}0.029 \\
(2.89)\end{array}$ & $\begin{array}{l}0.029 \\
(2.90)\end{array}$ \\
\hline Treat $_{i} \times$ Post 3 & & & & $\begin{array}{l}0.027 \\
(2.18)\end{array}$ & $\begin{array}{l}0.027 \\
(2.18)\end{array}$ \\
\hline Controls & No & Yes & Yes & Yes & Yes \\
\hline Segment FE & Yes & Yes & Yes & Yes & Yes \\
\hline Period FE & Yes & Yes & Yes & Yes & Yes \\
\hline Adj. R-squared & 0.033 & 0.088 & 0.078 & 0.078 & 0.078 \\
\hline $\mathrm{N}$ of funds & 1,684 & 1,619 & 1,619 & 1,619 & 1,619 \\
\hline Observations & 210,749 & 197,484 & 197,484 & 197,484 & 197,484 \\
\hline
\end{tabular}


Table 9. Flow-Performance Relationship

The dependent variable is monthly net percentage fund flows. The independent variables include the military dummy and its interaction terms with lagged performance variables. The setup of the regressions is otherwise identical to the baseline specification (3) of Table 2 and includes the standard set of control variables. Standard errors are double-clustered by fund and month-year. t-statistics are reported in parentheses.

\begin{tabular}{|c|c|c|c|c|}
\hline & & pendent & Fund Fl & \\
\hline & (1) & $(2)$ & $(3)$ & (4) \\
\hline Military & 0.004 & 0.010 & 0.012 & 0.011 \\
\hline & $(3.44)$ & $(2.30)$ & $(2.75)$ & $(2.48)$ \\
\hline Military $\times$ Performance rank & 0.010 & -0.024 & -0.031 & -0.025 \\
\hline & $(6.10)$ & $(-1.94)$ & $(-2.50)$ & $(-2.05)$ \\
\hline Military $\times$ Performance rank $^{2}$ & & 0.016 & 0.020 & 0.016 \\
\hline & & $(2.04)$ & $(2.57)$ & $(2.10)$ \\
\hline Performance rank $^{2}$ & & 0.011 & 0.010 & 0.012 \\
\hline & & $(5.34)$ & $(4.98)$ & $(5.66)$ \\
\hline Performance rank & 0.012 & -0.005 & -0.004 & -0.006 \\
\hline & $(15.68)$ & $(-1.62)$ & $(-1.36)$ & $(-1.84)$ \\
\hline Controls & Yes & Yes & Yes & Yes \\
\hline Period FE & Yes & Yes & Yes & No \\
\hline Segment FE & Yes & Yes & Yes & No \\
\hline Family FE & No & No & Yes & No \\
\hline Segment $\times$ Period FE & No & No & No & Yes \\
\hline Adj. R-squared & 0.266 & 0.267 & 0.276 & 0.271 \\
\hline $\mathrm{N}$ of funds & 2,412 & 2,412 & 2,406 & 2,064 \\
\hline Observations & 170,371 & 170,371 & 170,363 & 169,857 \\
\hline
\end{tabular}


Table 10. Microlevel Evidence From an Online Experiment

This table presents results of the Amazon Mechanical Turk online investment experiment. Panel A shows the fraction of money invested in fund $\mathrm{A}$ if it is managed by a military-experienced manager or by a manager without such experience, the difference between the amounts invested, and the respective t-statistic. All of the participants are U.S. mutual fund investors. Panel B shows the estimates of money invested in fund A regressed on a Military fund dummy variable and participant demographic characteristics. The Military fund indicator takes the value of one for funds which are randomly assigned to be military-managed and zero otherwise. Controls include a gender dummy and a dummy for old investors (above median biological age). Columns (1) and (4) present results for the full sample of subjects. Columns (2) and (3) present results for the two subsamples by selfreported participant party affiliation, namely Democrats and Republicans. t-statistics are reported in parentheses.

\begin{tabular}{|c|c|c|c|c|}
\hline \multicolumn{5}{|c|}{$\overline{\text { Panel A. Average distributions (Rounds including military managers) }}$} \\
\hline & \multicolumn{2}{|c|}{$\%$ of funds allocated to fund $\mathrm{A}$ if } & \multirow{2}{*}{$\begin{array}{c}\text { Difference } \\
\text { (mil. - nonmil.) }\end{array}$} & \multirow[b]{2}{*}{ t-statistic } \\
\hline & military manager & nonmilitary manager & & \\
\hline Round 2 & 63.04 & 59.50 & 3.54 & 1.96 \\
\hline Round 4 & 13.36 & 10.18 & 3.17 & 5.55 \\
\hline Round $2+$ Round 4 & 38.20 & 34.84 & 3.36 & 2.20 \\
\hline \multicolumn{5}{|c|}{ Panel B. Regressions (Rounds including military managers) } \\
\hline & All subjects & Democrats & Republicans & Interactions \\
\hline \multirow{3}{*}{ Military fund } & (1) & $(2)$ & $(3)$ & (4) \\
\hline & 3.36 & 4.32 & 4.53 & 0.68 \\
\hline & $(2.20)$ & $(1.72)$ & $(1.89)$ & $(0.27)$ \\
\hline \multirow[t]{2}{*}{ Female $\times$ Military fund } & & & & 0.08 \\
\hline & & & & $(0.98)$ \\
\hline \multirow[t]{2}{*}{ Old $\times$ Military fund } & & & & 5.42 \\
\hline & & & & $(1.77)$ \\
\hline Controls & Yes & Yes & Yes & Yes \\
\hline Adj. R-squared & 0.01 & 0.01 & 0.01 & 0.01 \\
\hline Observations & 1,608 & 610 & 658 & 1,608 \\
\hline
\end{tabular}


Table 11. Ex-Military Managers and Window Dressing

This table relates manager's military background to window dressing activities. The dependent variable is either Rank Gap or Backward Holding Return Gap (BHRG). The main independent variable is the military dummy that equals one if a fund is single-managed by an individual with military background in a given month and zero if an active manager does not have a military background. Rank Gap is the difference between a fund's performance rank and the two ranks based on winner and loser stocks proportions in the reported holdings. BHRG is calculated by taking the difference between the net return of a hypothetical portfolio that is based on the last quarter fund's holdings and the fund's actual return. The set of control variables is comprised of variables described in Table 1 and in Appendix A. All of the regression specifications include period and segment fixed effects. Period FE stands for quarter-year time fixed effects. Standard errors are based on clustering at the fund level. The corresponding t-statistics are reported in parentheses.

\begin{tabular}{lcccccc}
\hline \hline & \multicolumn{2}{c}{ Full Sample } & \multicolumn{2}{c}{ Bottom 20\% perf. } & \multicolumn{2}{c}{ Top 20\% perf. } \\
\cline { 2 - 7 } Military & Rank Gap & BHRG & Rank Gap & BHRG & Rank Gap & BHRG \\
\cline { 2 - 7 } & -0.024 & -0.006 & -0.018 & -0.009 & -0.020 & -0.010 \\
& $(-2.96)$ & $(-1.68)$ & $(-1.82)$ & $(-2.63)$ & $(-1.83)$ & $(-2.90)$ \\
Controls & & & & & & \\
Segment FE & Yes & Yes & Yes & Yes & Yes & Yes \\
Period FE & Yes & Yes & Yes & Yes & Yes & Yes \\
R-squared & 0.198 & 0.059 & Yes & Yes & Yes & Yes \\
N of funds & 924 & 924 & 695 & 0.088 & 0.191 & 0.119 \\
Observations & 10,388 & 10,388 & 2,134 & 2,134 & 2,319 & 2,319 \\
\hline \hline
\end{tabular}




\section{Table 12. Matching Funds}

This table reports results of the matched sample analysis. In specification (1), we report the baseline regression results. In the following specifications, we keep the regression setup, but estimate regressions on various samples of matched funds. To identify a match for a military-managed fund, we find a nonmilitary-managed counterpart fund based on the similarities of the set of matching criteria in a given month. We use the following matching criteria: manager's gender, foreignness of a name, biological age, industry experience, and fund's segment, family, size, age, performance, expense ratio, turnover, and the share of marketing expenses (NSAR-B filings) in total expenses. The first matching procedure identifies nonmilitary fund as a match if values of the non-categorical variables are in the range of five percent from military-managed counterpart fund values in a given month. In these regressions the set of control variables is identical to the baseline specification and standard errors are double-clustered by fund and month-year. The table also reports the estimates of the propensity score nearest neighbourhood matching (the second matching procedure) on the set of fund characteristics and t-statistics based on the bootstraped standard errors.

(1) No Matching (Table 2, Specification 3)

Matching fund and manager characteristics:

(2) Time and gender

(3) Time, gender, and foreign name

(4) Time, gender, and segment

(5) Time, gender, segment, and fund family

(6) Time, gender, segment, and fund size

(7) Time, gender, segment, and fund age

(8) Time, gender, segment, and manager age

(9) Time, gender, segment, and manager tenure

(10) Time, gender, segment, and performance

(11) Time, gender, segment, and marketing exp.

Propensity score matching on the following fund characteristics:

(12) Perf., and size

(13) Perf., size, and expense ratio

(14) Perf., size, expense ratio, and turnover

(15) Perf., size, expense ratio, turnover, and age

(16) Perf., size, expense ratio, turnover, age, and lagged flows

\begin{tabular}{ccc}
\multicolumn{3}{c}{ Dep. Variable: Fund Flows } \\
\hline Coefficient & t-stat. & Obs. \\
\hline 0.003 & 3.20 & 170,371 \\
& & \\
0.003 & 3.20 & 155,767 \\
0.002 & 2.63 & 110,348 \\
0.003 & 3.21 & 155,109 \\
0.004 & 2.73 & 25,612 \\
0.004 & 3.12 & 140,866 \\
0.003 & 3.25 & 143,179 \\
0.003 & 3.62 & 135,813 \\
0.002 & 2.81 & 139,729 \\
0.003 & 2.26 & 20,934 \\
0.004 & 3.22 & 83,833 \\
& & \\
0.007 & 9.78 & 47,225 \\
0.006 & 6.85 & 26,103 \\
0.006 & 7.15 & 26,030 \\
0.005 & 6.49 & 25,962 \\
0.003 & 3.13 & 25,891 \\
\hline
\end{tabular}




\section{Table 13. Alternative Dependent Variable Definition}

This table reports results for the alternative measures of fund flows as dependent variables. We use absolute dollar flows and the change of a fund's market share as in Spiegel and Zhang (2013) instead of relative flows as dependent variable. Specifications (1) and (2) report the regression estimates of monthly absolute dollar flows on the military dummy. These specifications differ in fixed effects applied, but the regression setup is otherwise identical to the baseline specification of Table 2 and includes the standard set of control variables. Specifications (3) reports the regression estimates of the change of a fund's market (more precisely, segment) share on the military dummy. We use quantile regression to estimate the coefficient and also include the standard set of controls and fixed effects. For presentation purposes, we report the coefficient of change of a fund's market share as multiplied by 100. Standard errors are double-clustered by fund and month-year and t-statistics are reported in parentheses.

\begin{tabular}{lcccc}
\hline \hline & \multicolumn{2}{c}{ Modified Dependent Variable } \\
\cline { 2 - 3 } & \multicolumn{2}{c}{ Absolute fund flows } & & Change in fund's market share \\
\cline { 2 - 3 } Military & $(1)$ & 3.472 & $(3)$ \\
\cline { 2 - 3 } & 3.294 & $(2.02)$ & 0.003 \\
Controls & $(1.88)$ & Yes & $(5.15)$ \\
Segment FE & Yes & No & Yes \\
Period FE & Yes & No & Yes \\
Segment $\times$ Period FE & Yes & Yo & Yes & Yes \\
R-squared (Pseudo $\left.\mathrm{R}^{2}\right)$ & 0.067 & 0.070 & Yes \\
N of funds & 2,412 & 2,412 & 0.200 \\
Observations & 170,371 & 170,371 & 2,412 \\
\hline \hline
\end{tabular}




\section{Table 14. Fund Performance and Persistence}

This table shows additional results for fund performance and performance persistence of military managers vs. nonmilitary managers. Panel A reports results from a regression with the equalweighted return of a difference portfolio that is long in all funds that are single-managed by an individual with military background and short in all funds with nonmilitary managers as the dependent variable. Portfolio is rebalanced on a monthly basis. Estimates of fund performance are measured using the capital asset pricing model (column (1)), the Fama and French (1993) threefactor model (column (2)) and the four-factor model of Carhart (1997) in column (3). Results for both net and gross (before expenses) performance are reported. Panel B shows results for the average time-series standard deviation of monthly performance ranks of military and nonmilitary managers along with the differences between the group means. The corresponding t-statistics are in parentheses and are based on robust standard errors.

\begin{tabular}{|c|c|c|c|c|}
\hline & & $\begin{array}{c}\mathrm{CAPM}_{t}^{m-n} \\
(1)\end{array}$ & $\begin{array}{c}\text { Three-Factor }_{t}^{m-n} \\
(2)\end{array}$ & $\begin{array}{c}\text { Four-Factor }_{t}^{m-n} \\
(3)\end{array}$ \\
\hline \multicolumn{5}{|l|}{ Net performance } \\
\hline & Alpha $_{t}$ & 0.000 & 0.000 & 0.000 \\
\hline & & $(0.38)$ & $(1.50)$ & $(1.49)$ \\
\hline & R-squared & 0.012 & 0.202 & 0.202 \\
\hline \multicolumn{5}{|c|}{ Gross performance } \\
\hline & Alpha $_{t}$ & 0.001 & 0.001 & 0.001 \\
\hline & & $(1.03)$ & $(1.24)$ & $(1.22)$ \\
\hline & R-squared & 0.009 & 0.208 & 0.208 \\
\hline \multicolumn{5}{|c|}{ Panel B: Performance Persistence } \\
\hline \multirow{3}{*}{\multicolumn{2}{|c|}{$\begin{array}{l}\text { Persistence }{ }^{\text {net }} \\
\text { Persistencegross }\end{array}$}} & Military managers & Nonmilitary managers & Difference \\
\hline & & 0.279 & 0.281 & -0.002 \\
\hline & & 0.269 & 0.275 & -0.006 \\
\hline
\end{tabular}




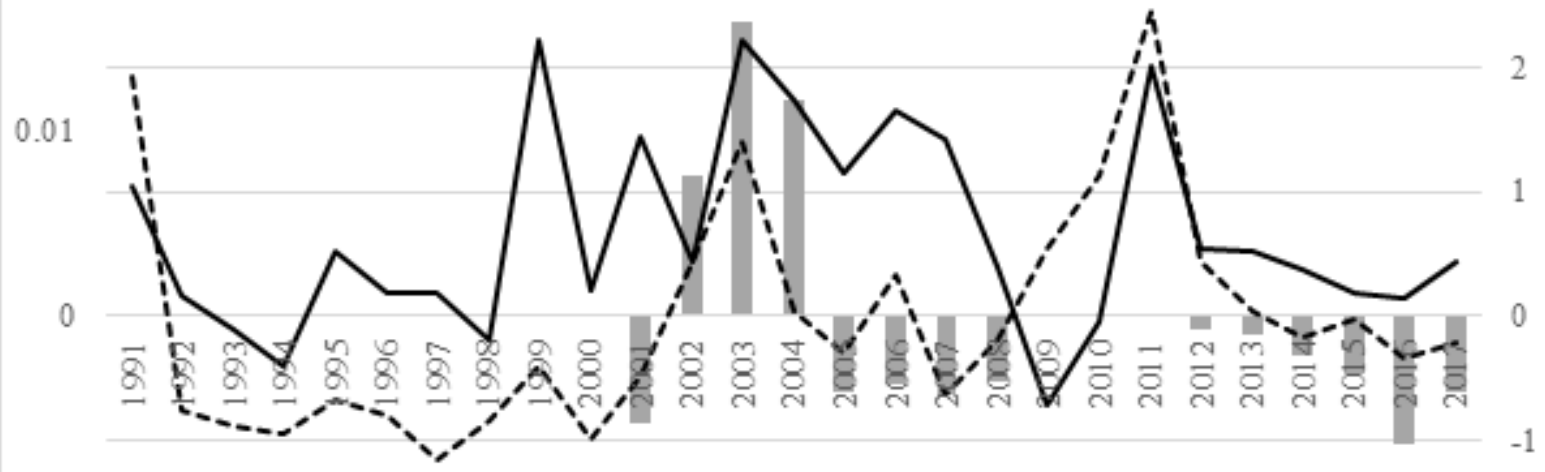

Fig. 1. Difference in fund flows and confidence in military. Graph plots the time series of difference in fund flows between the funds that are single-managed by military managers and nonmilitary managers (solid line) and the dynamic of Gallup Poll's normalized confidence in the military index by (dashed line). Bars indicate the values of normalized satisfaction in nation's military strength and preparedness (Gallup Poll). 


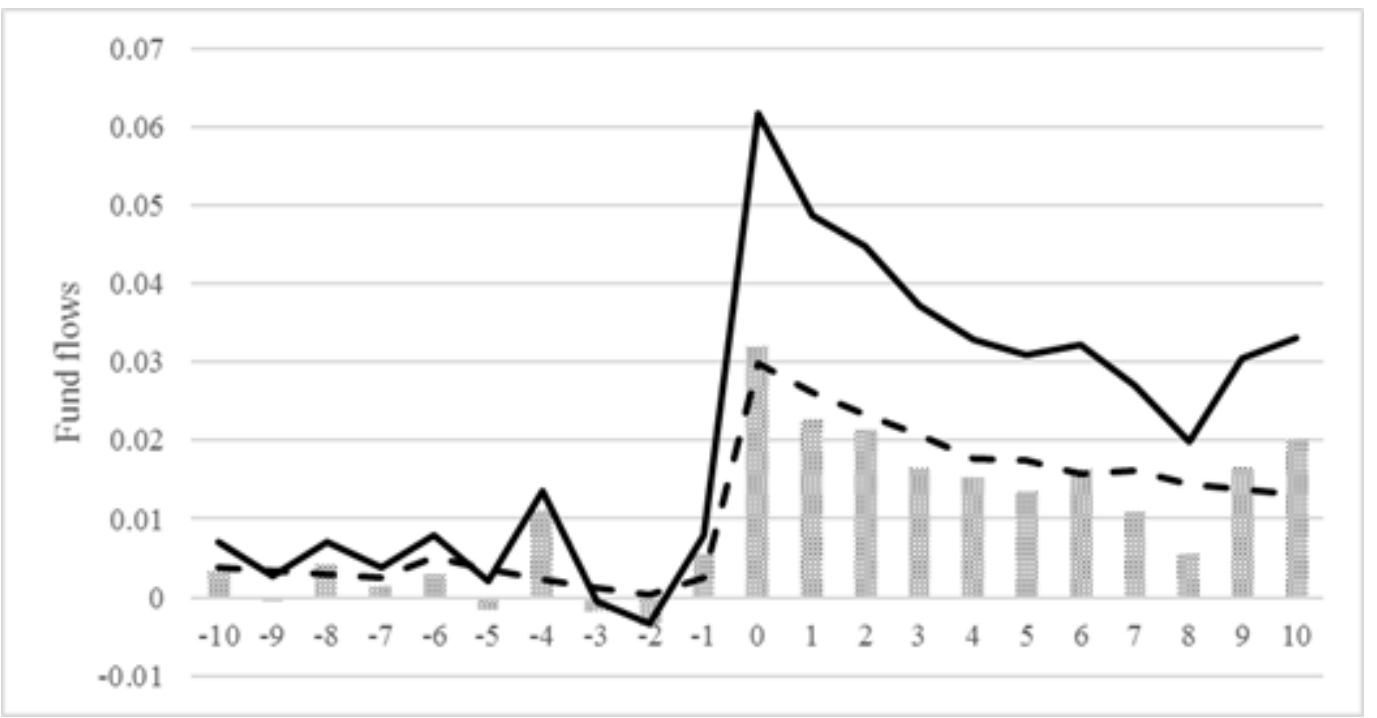

Fig. 2. Dynamics of average monthly net inflows into military-managed funds vs. nonmilitary-managed funds. Graph plots the dynamics of net fund flows of the funds that become single-managed by military managers (solid line) and the dynamic of net fund flows of the funds that shift to single-management by nonmilitary managers (dashed line). Bars indicate the difference in net inflows between the two groups. Date zero is the month of manager change. 


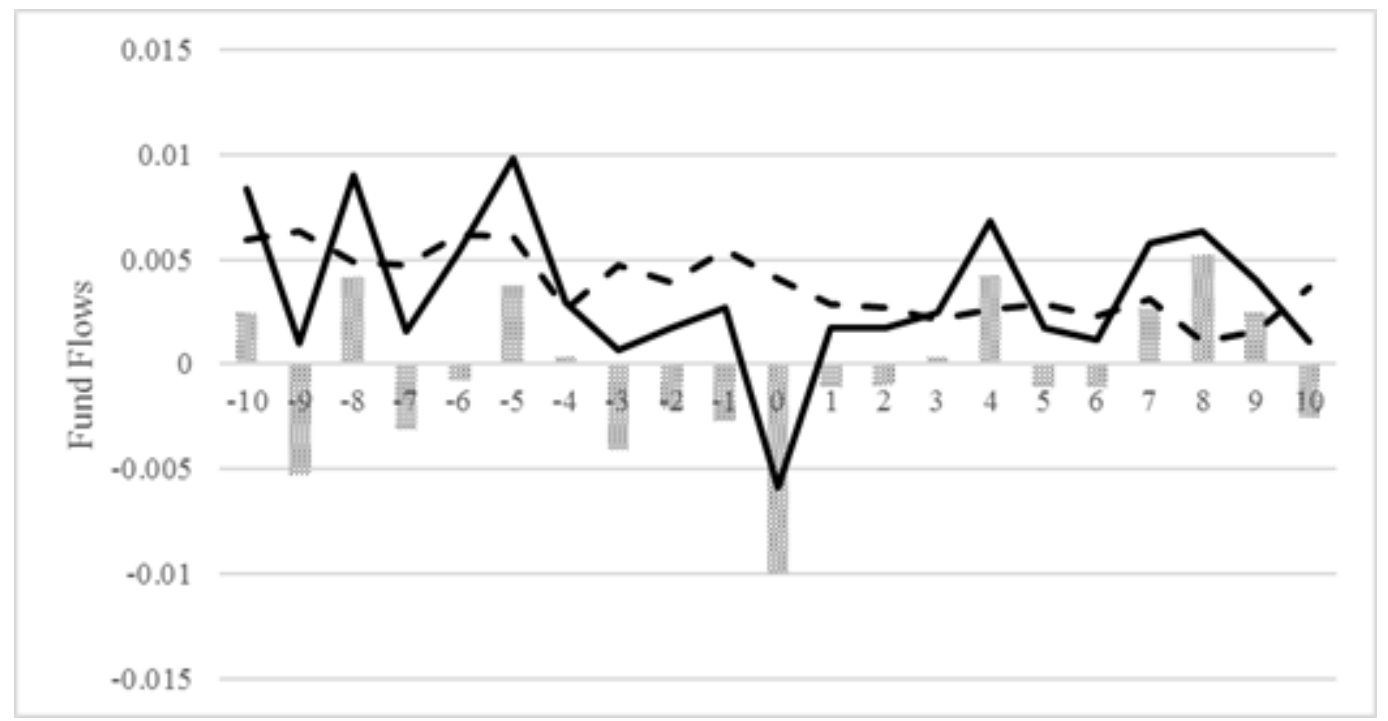

Fig. 3. Dynamics of average monthly net inflows into military-managed funds vs. nonmilitary-managed funds around the dates of management change. Graph plots the dynamics of net fund flows of the funds with leaving military managers (solid line) and nonmilitary managers (dashed line). Bars indicate the difference in net inflows between the two groups. Date zero is the month of manager change. 

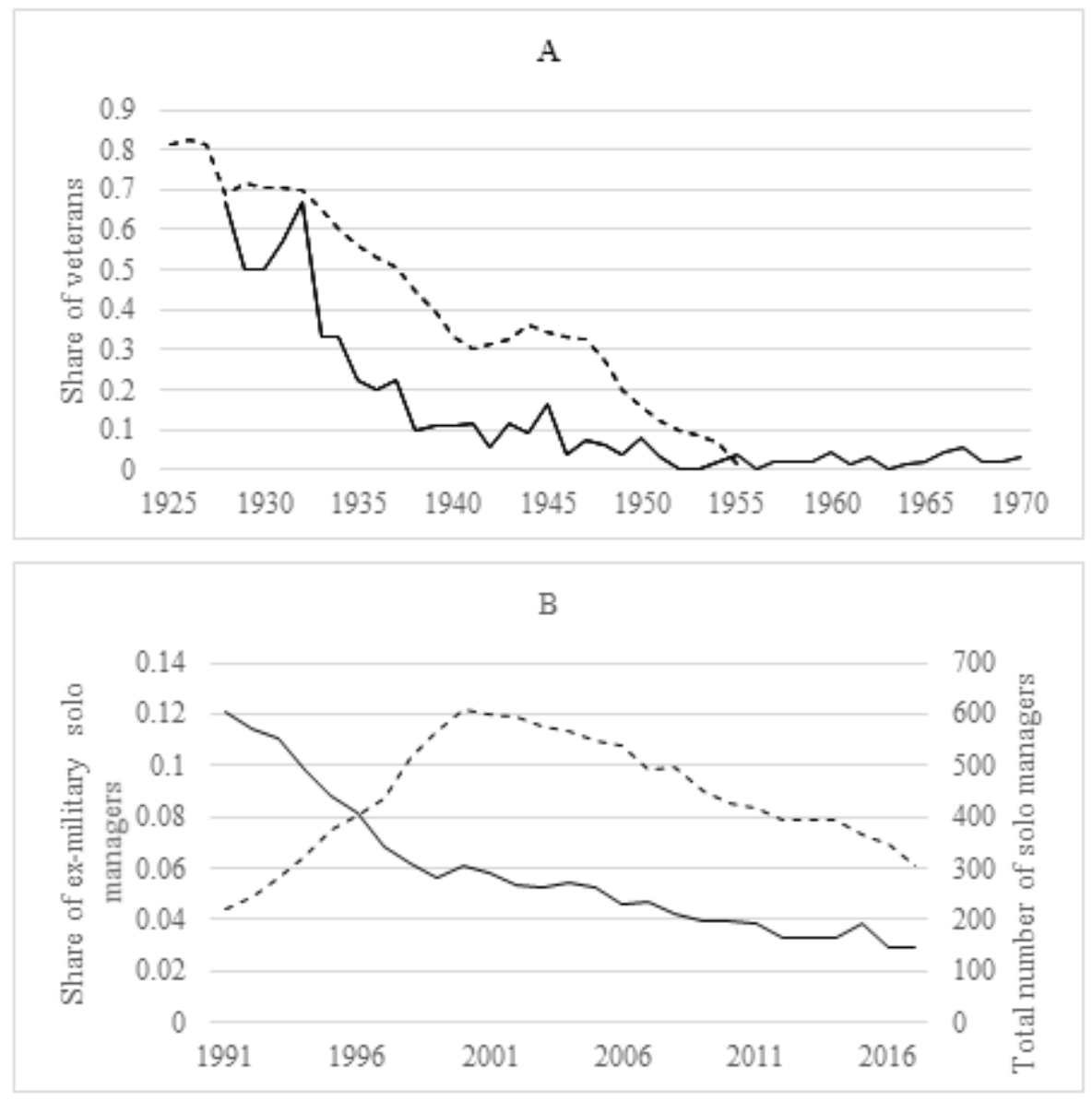

Fig. 4. Share of veterans. A, among fund managers by birth cohort, 1925-1970. B, among fund managers by year, 1991 - 2017. Graph A depicts the share of veterans among all of the solo mutual fund managers in our sample by birth cohort (solid line) and the share of educational attainment (college level) of veteran population using data from $3 \%$ of the 1980 decennial census, restricted to white males. Graph B plots the share of military managers who single-managed at least one U.S. equity mutual fund for at least one full month (solid line) in a given year and the total number of solo managers (dashed line) by year. 